\title{
إشكالات الفصل والوصل بين المنهجية والمذهبية في الفكر الإسلامي: الإشكال المفهومي نموذجاً
}

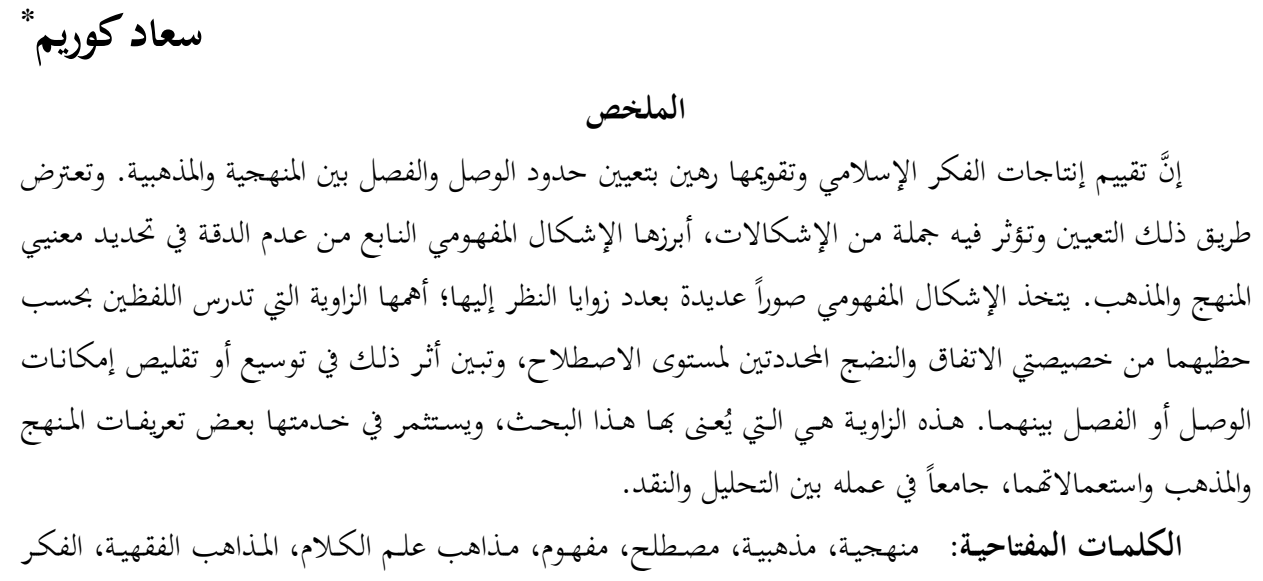

\section{The conceptual confusion of connection and separation between methodology and doctrine in Islamic thought \\ Abstract}

The evaluation of products of Islamic thought passes through the delimitation of the boundaries between methodology and doctrine. That delimitation encounters, and is influenced by, a series of problems, most notably the conceptual confusion caused by the lack of precision in the definition of the concepts. The confusion takes several forms depending on what perspective one sees it from. This paper focuses on the view that studies the words "methodology" and "doctrine" according to their terminological level, which is defined by the amount of their maturity and the level of agreement upon their meaning. It also shows the impact of the terminological level on extending or reducing the possibilities of connection or separation between methodology and the doctrine. For this purpose the author has critically analyzed some definitions and uses of the two concepts; namely, methodology and doctrine.

Keywords: methodology, doctrine, ideology, term, concept, schools of theology, schools of Islamic jurisprudence, Islamic thought.

$$
\begin{aligned}
& \text { * دكتوراه في الدراسات القرآنية، كلية الآداب والعلوم الإنسانية، جامعة مولاي إسماعيل، مكناس، المغرب، باحثة في } \\
& \text { الدراسات القرآنية. البريد الإلكتروني: Souadkourime@gmail.com }
\end{aligned}
$$

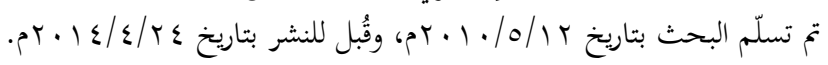


مقدمة:

تعـترض صـوبات عديـدة طريـق التطبيـق المنهجـي في بجـالات الفكــ الإسـلامي،

والتقييمَ الموضوعي لما ينتجه ذلك الفكر. ومنها صعوبة تحديد مواضع الفصل والوصل بين

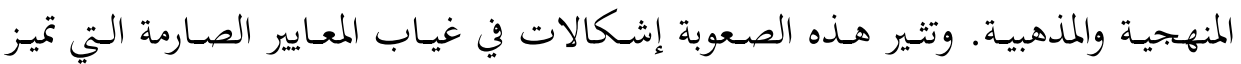

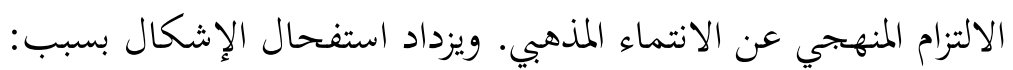

- تـداخل المنهجيـة والمذهبيـة أحيانـاً، لا سيما أنَّ المنـاهج في العلوم الإسـلامية قـد

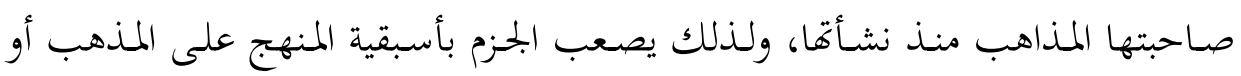

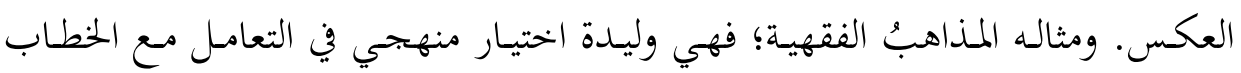

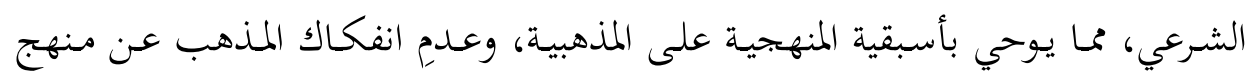

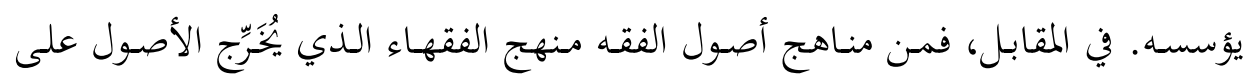

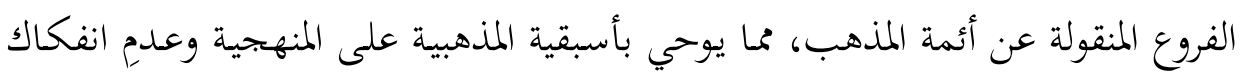

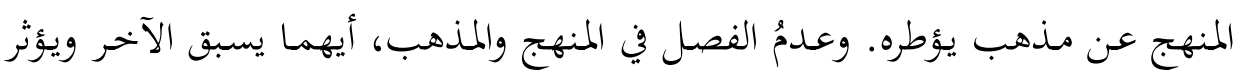
فيه، يجول دون التمييز التام بين المنهجية والمذهبية.

- تعدد معاني المنهجية والمذهبية تبعاً لتعدد معاني المنهج والمذهبب. وتراؤح المعاني

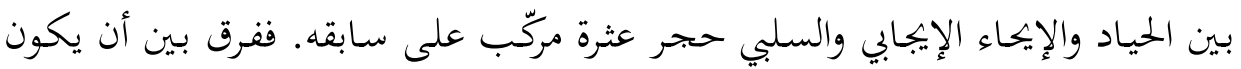

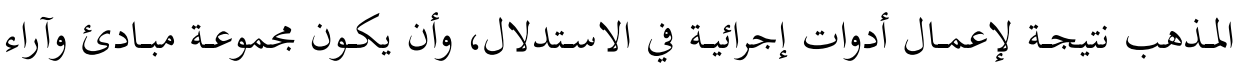

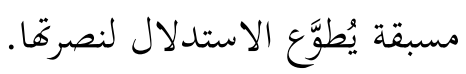

وعلى الرغم من هذه الصعوبات، فالفصل والوصل بين المنهجية والمذهبية في الفكر

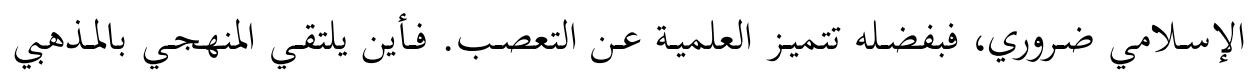
وأين يفترقان؟

إنَّ الإجابـة رهينـة بمعالجــة إشـكالات المنهجيـة والمذهبيـة، سـواء منهـا الإشـكال التصوري المفهومي، أو التجريدي النظري، أو العملي التطبيقي. والنوع الأول هو بحـال هذه الدراسة؛ لأنَّ المفاهيم تؤثر على الفعل في الواقع بمقتضاها. ولهذا التأثير بعدان هما: 


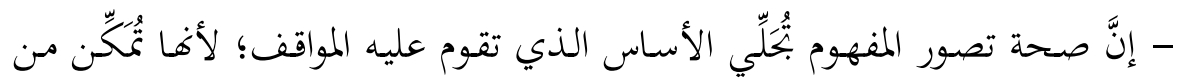
اتخاذ مواقف صحيحة من المفهوم وموضوعه وبجاله المعرفي. - إنَّ صحة تصوّر المفهوم ترسم مسار مـا يليها من خطوات؛ لأهـا تضمن صحة التعامل النظري والعملي مع المفهوم وموضوعه وبحاله المعرفي. ويَتُج الإشكال المفهومي عن اختلاف العلاقة بين "المنهج" و "المذهب"، وله صور

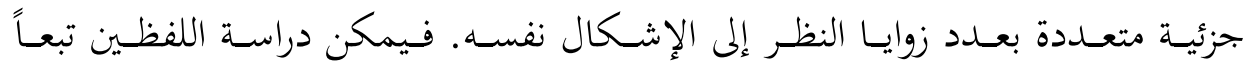

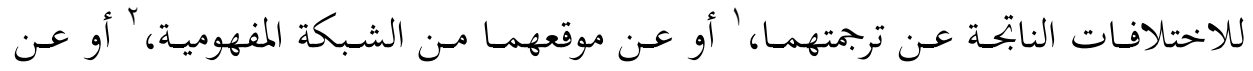

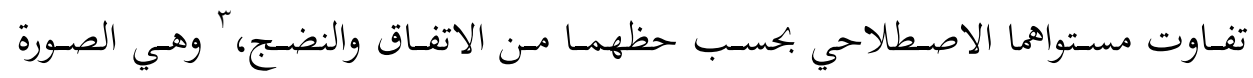

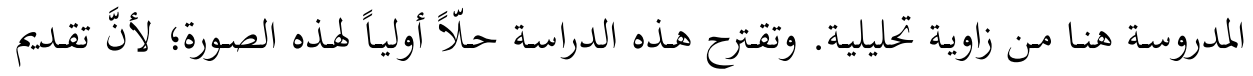

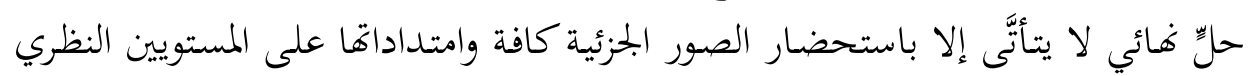
والتطبيقي.

أولاً: حظ "المنهج" و "المذهب" من الاتفاق وأثره في الوصل والفصل بينهما ا ـ حظ "المنهج" و "المذهب" من الاتفاق:

إنَّ العنصر المحلِّد لقوة الاصطلاح هو حظ اللفظ من الاتفاق والنضهج؛ فبإذاكان

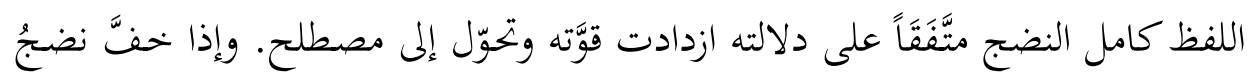
اللفظِ ولم يُتنق على دلالته ضعفت قوته وتحوّل إلى مفهوم.

وبحسب معاني "المنهج" و "المذهب" يظهر تفاوت حظيهما من خصيصة الاتفاق.

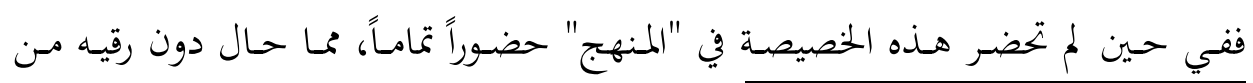

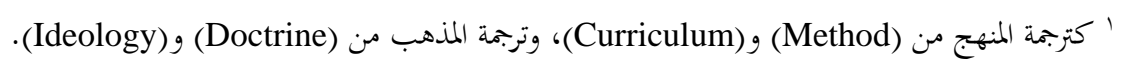

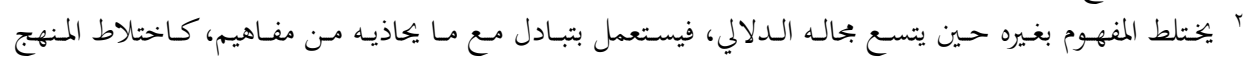

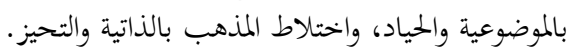

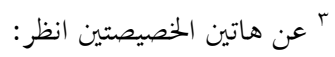

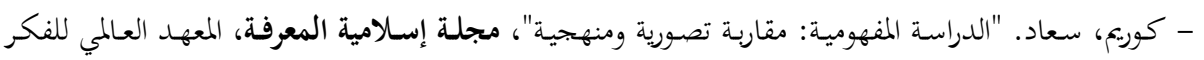

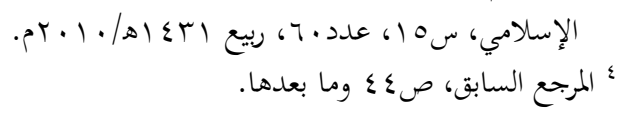




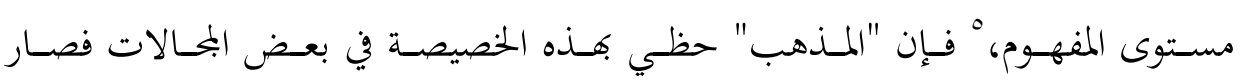
مصطلحاً، ولم يحظ به في غيرها فبقي مفهوماً.

وقع تداول مصطلح "المذهب" في بحالي الفقه وعلم الكالام؛ إذ استعمل في الأول

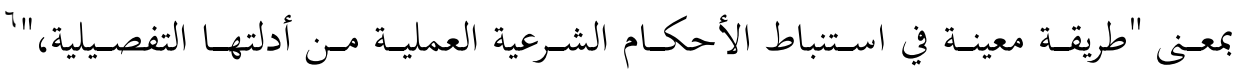

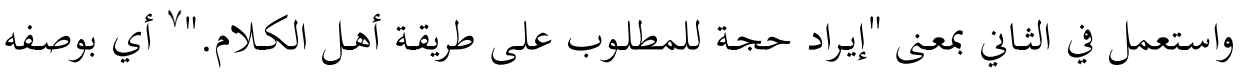

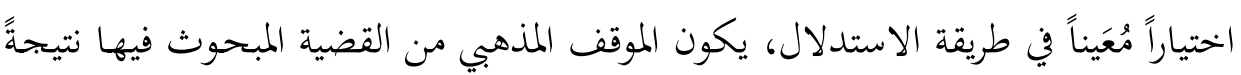

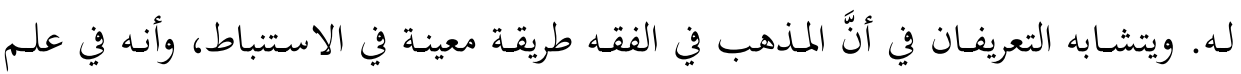
الكلام طريقة معيّنة في الاستدلال.

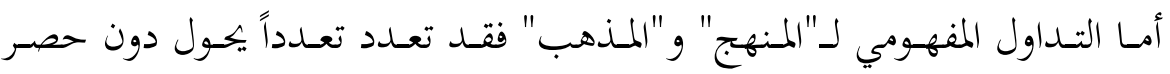

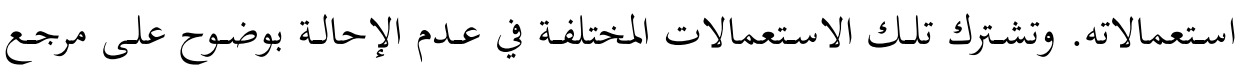

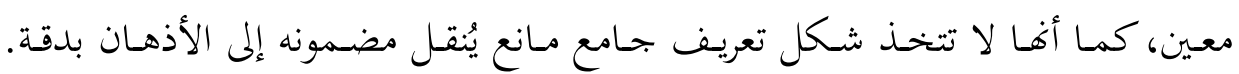
ويتأكد ذلك بتحليل بعض تعريفات المنهج والمذهب.

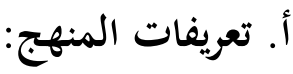

ثمـة تعريفـات متعـددة ومتنوعـة للمـنهج؛ فمـنهم مـن يـرى بأنهه خطـة منظمـة لعـدة

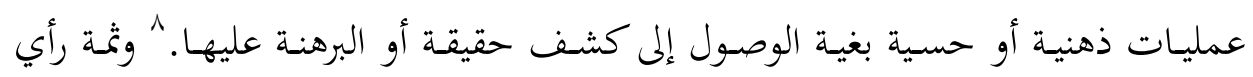
يقول بأنه الطريق المؤدي إلى الكشف عن الحقيقة في العلوم بوساطة طائفة من القواعد

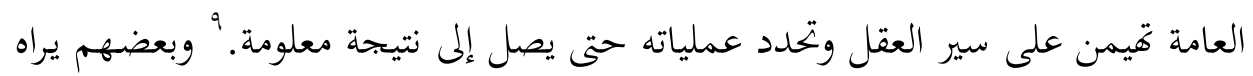

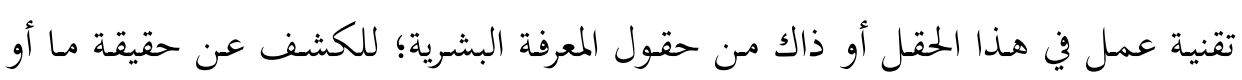

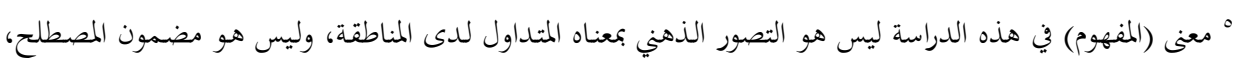

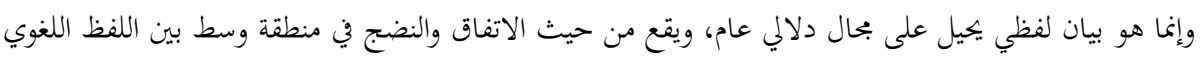
والمصطلح. انظر :

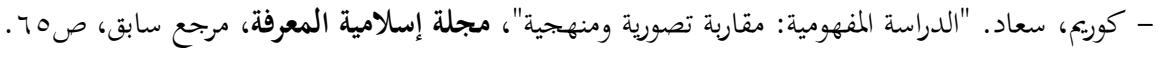

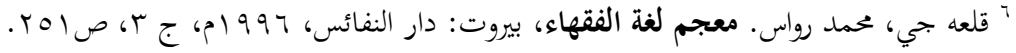

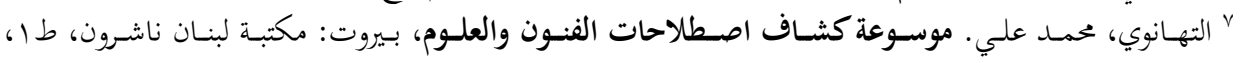

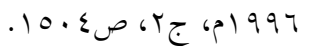

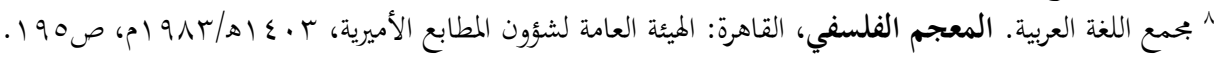

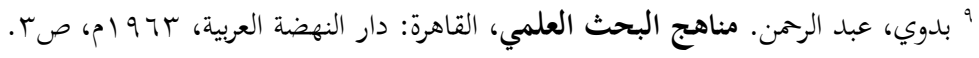




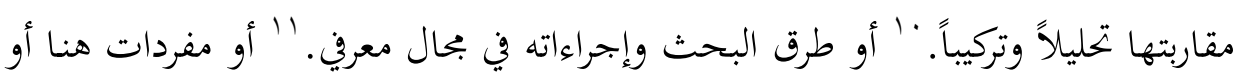

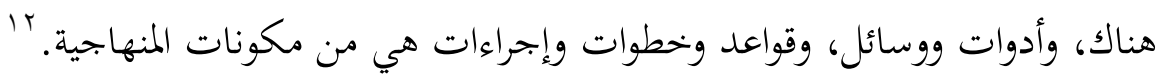

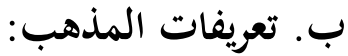

كما أنَّ للمنهج تعريفات متعددة، فللمذهب تعريفات كذلك؛ فمنهم من يرى بأنه

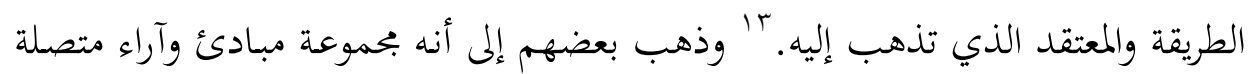

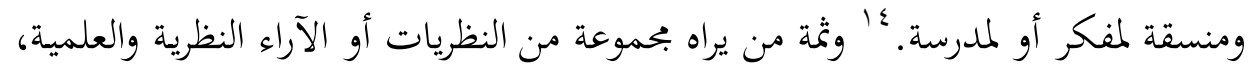
في مجال من بحالات الفكر أو الحياة، تكون في الغالب مترابطة متسقة فيما بينها، ولها مناه مثثلون يقولون بصوابها، ويعملون على نشرها بين الآخرين والدفاع عنها. 10 وممـا سـبق نلمـح اختلافـات بـين تعريفـات المـهجج، وكـذلك اختلافـات في تعريفـات المذهب، فمن أهم الاختلافات بين تعريفات المنهج ما يأين: - إنَّ التعريفـات الثلاثــة الأولى أدق لجمعهــا بــن عنصـري الوسـيلة والغايـة، بينمـا اقتصرت بقية التعريفات على الوسيلة. وكلما كثرت مكونات التعريف أضيفت محددات جديدة بتعل المفهوم أكثر دقة. - إنَّ التعريف الخامس بحاوز بيان الوسائل إلى تحديد موقع المنهج ضمن نسق أكبر، هو المنظومة التي ينتمي إليها، وهي المنهاجية.

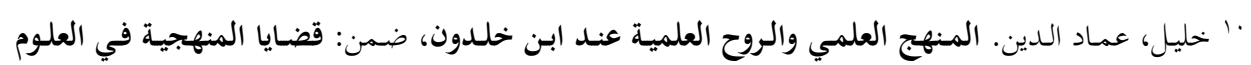

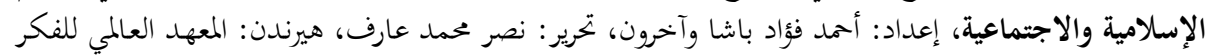

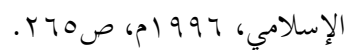

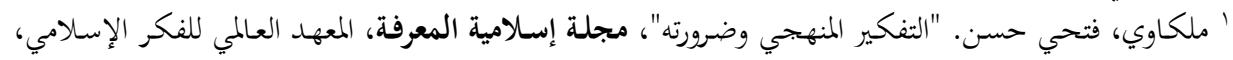

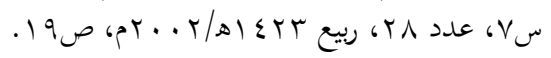

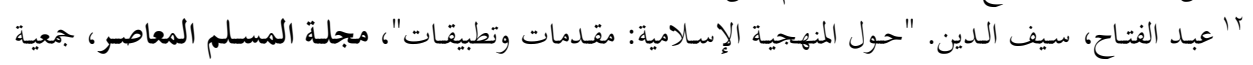

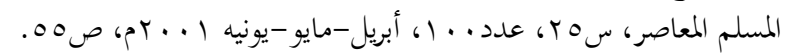

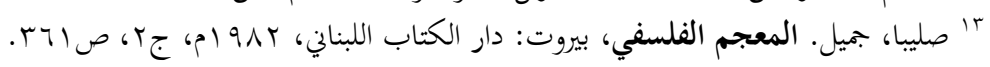

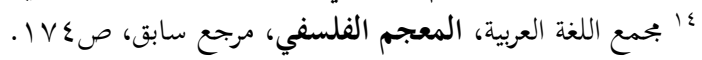

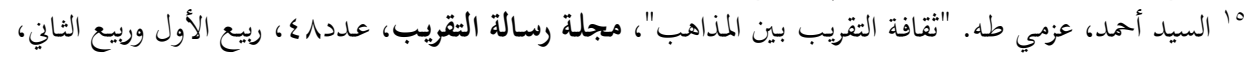




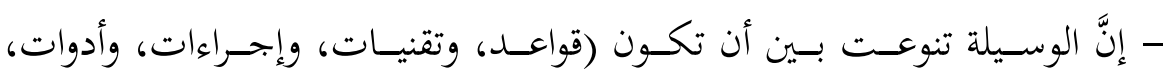

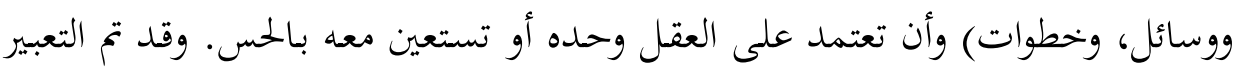

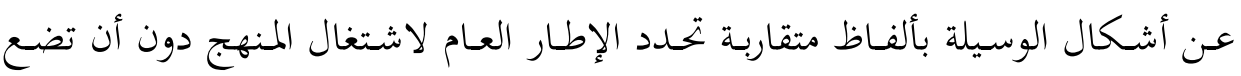

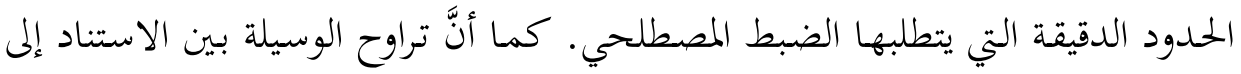

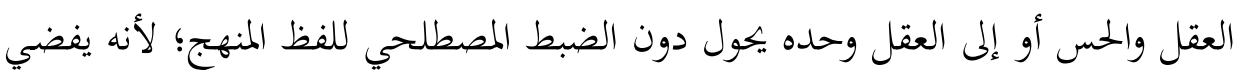
إلى الاختلاف حول بحال اشتغال المنهج.

- إنَّ الغاية من المنهج تتنوع بين الكشف عن الحقيقة ومقاربتها والبرهنة والاستدلال

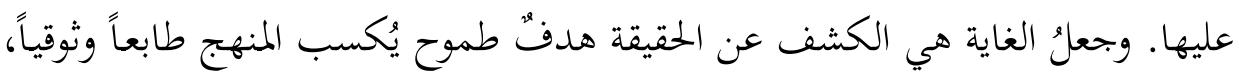

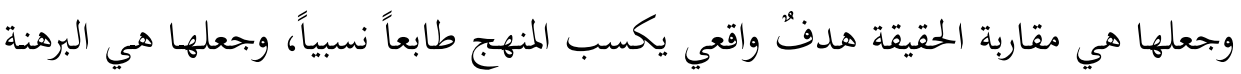

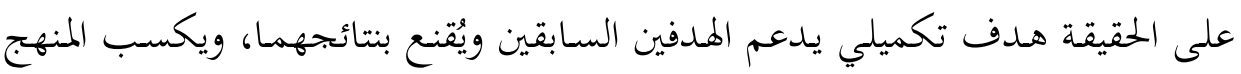

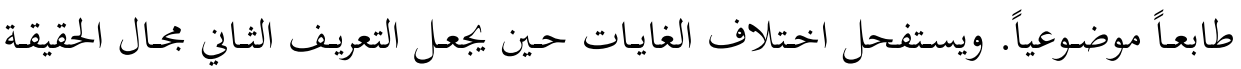

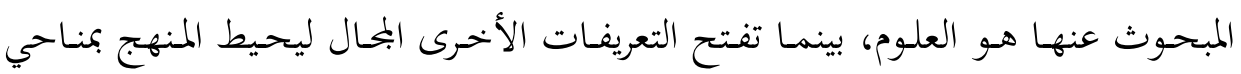

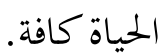

$$
\text { وهناك اختلافات بين تعريفات مفهوم المذهب هي: }
$$

- إنَّ التعريـف الثاني والثالث يمتويـان على ثلاثنة عناصـر، بينما يتضـمن التعريف الأول عنصراً واحداً.

- إنَّ العنصـر الأول مختلـف فيـه، هـل هـو (معتقــد، أو بحموعــة مبـادئ وآراء، أو

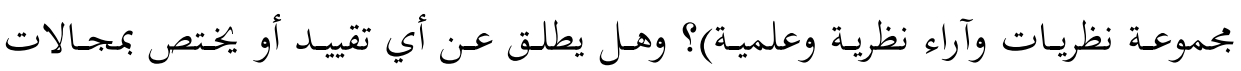
الفكر أو الحياة؟ نموعلبات

- إنَّ العنصـر الثـاني يصـف طبيعـة العنصـر الأول. وقـــ اشـترط التعريـف الثـاني أن تكون مكونات العنصر الأول متصلة ومنسقة، واشترط التعريف الثالث أن تكون مترابطة ومتسقة. ويوحي التنسيق بالتداخل الخارجي، بينما يوحي الاتساق بالانسجام الداخلي. - إنَّ العنصـر الثالـث يبـين الجهـة الحاملـة للعنصـر الأول. ويختلـف التعريفـان الثـاني والثالث في اعتبار شرط الكثرة في الجهة، فيؤكد التعريف الثالث على أهميته باستعمال 
الجمـع الصريح (مثثلون)، ولا يهتم التعريف الثـاني بـه فيقرن بـين لفظة (مفكـر) المفردة

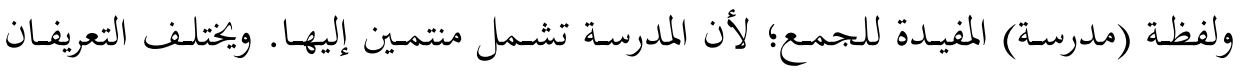

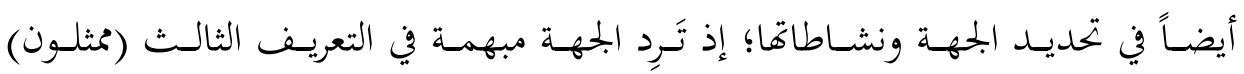

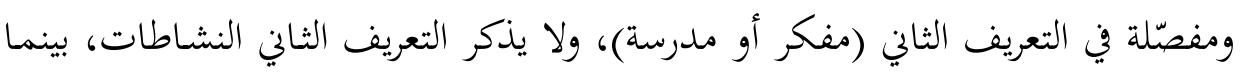

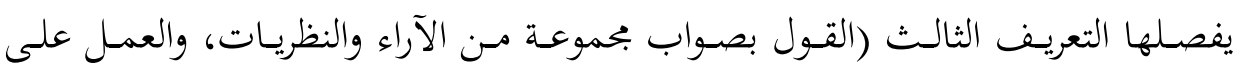
نشرها بين الآخرين والدفاع عنها).

\section{Y. أثر اختلاف معاني "المنهج" و "المذهب" في الوصل والفصل بينهما:}

يحول اختلاف معاني المنهج والمذهب دون وضوح العلاقة بينهما؛ متى تكون علاقة وصل أو فصل؟ فعلاقة مصطلح المذهب بمفهوم المنهج غير واضحة؛ لأفها تربط مصطلحاً

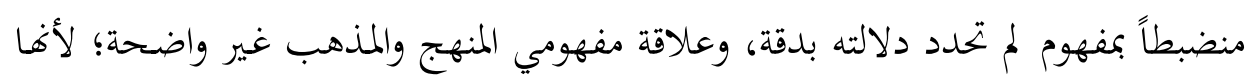
تربط مفهومين لم تحدد دلالتهما بدقة. لكن العلاقة الأولى أوضح لتضمنها عنصراً متفقاً عليه، بينما تتضمن العلاقة الثانية عنصرين مختلفاً فيهما.

إذن، فالحـل الأنسـب لتحديــ علاقـة المـنهج بالمـذهب هـو الاتفــاق على دلالـة للمفهومين ترفعهما إلى مرتبة مصطلح ملزم. يتحقق ذلك حين يغلب في الاتفاق الطابع

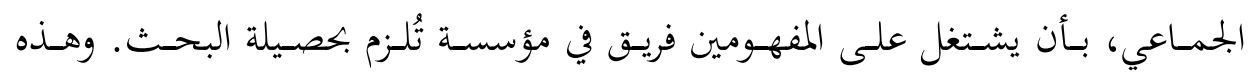

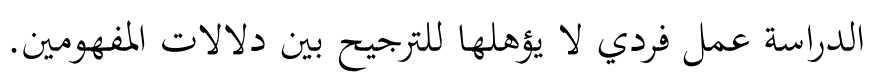

ويي انتظـار ارتقـاء المفهـومين إلى مرتبـة المصطلح تقتضي الموضـوعيةُ الاستقراءَ التـام لمعانيهما، والبحث عن سائر إمكانات الوصل والفصل بينهما. وكون هذه الدراسة عملاً

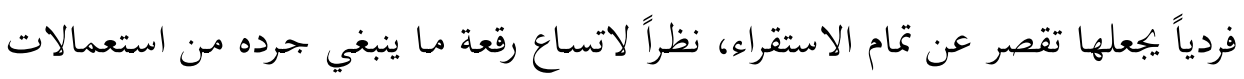

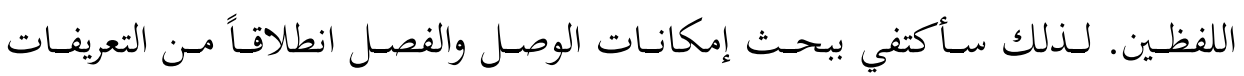
السـابقة. ويتوقف تحديد إمكانات الوصل والفصل بين المنهج والمذذهب على استثمار

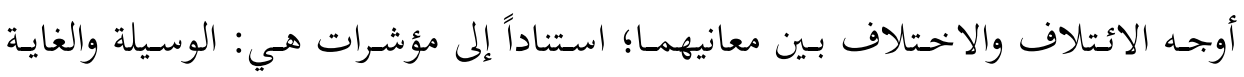
والمنظومة وبحال الاشتغال. 
أ. الاخستلاف في مؤشـر الوسسيلة وأثره في الفصـل والوصـل بسين "المسنهج"

و"المذهب":

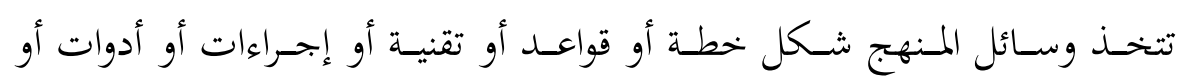

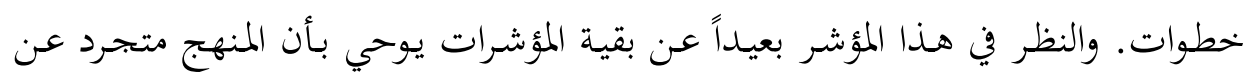

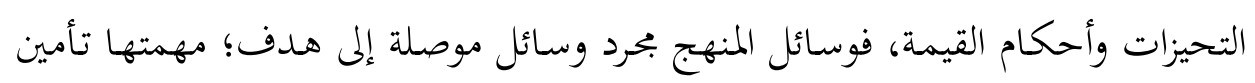
الانتقال من نقطة ابتداء البحث المنهجي إلى فايته.

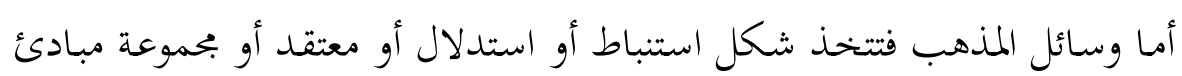

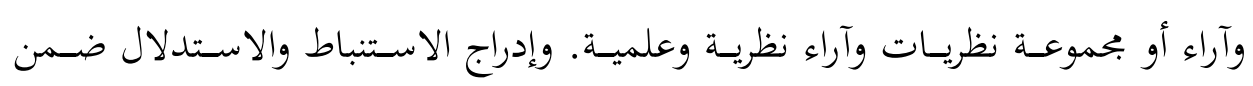

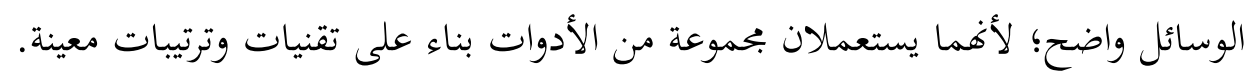

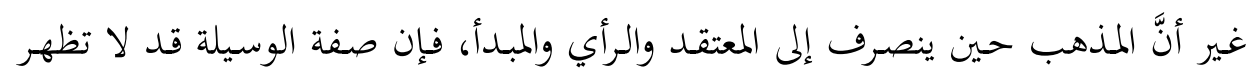

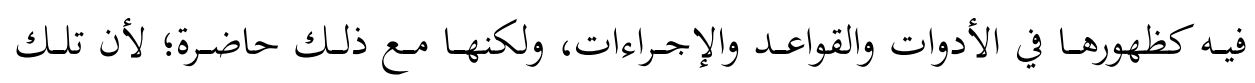

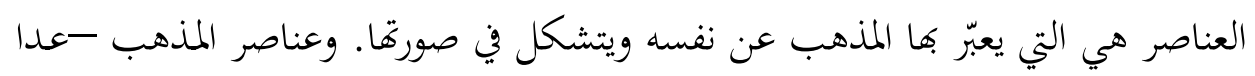

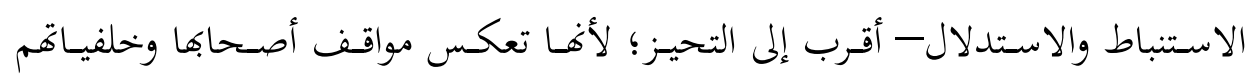
الفلسفية وقبلياهم المعرفية.

إن مقارنة المنهج بالمذهب في مؤشر الوسيلة تعرفنا على إمكانات الوصل والفصل

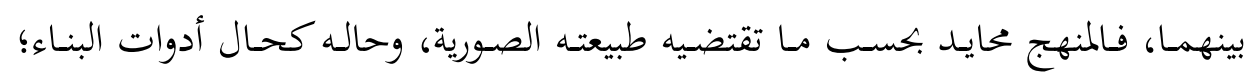

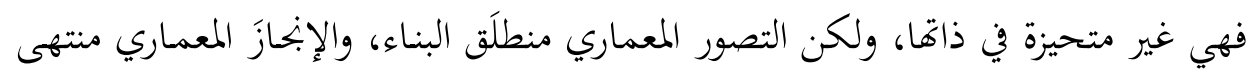

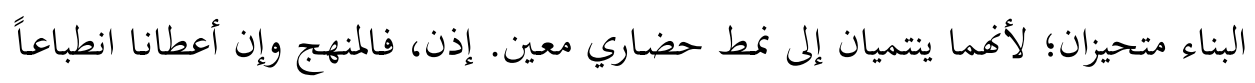

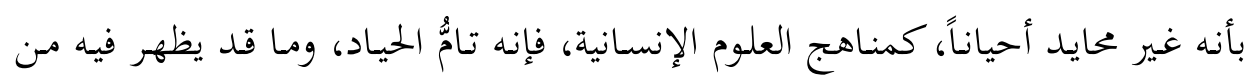

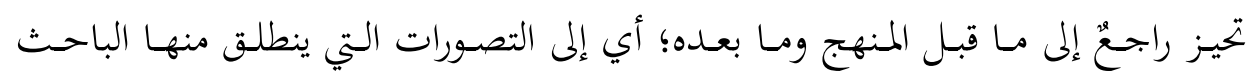
والقناعات التي يصل إليها.

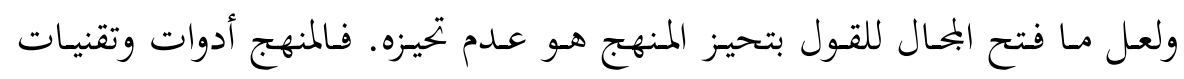

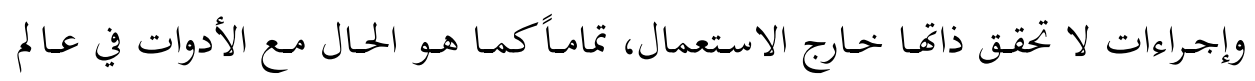


الأشـياء. فهـو ذو طـابع وظيفي إضـافة إلى طبيعتـه الصـورية، ولا يُنظر إليـه إلا بوصفه

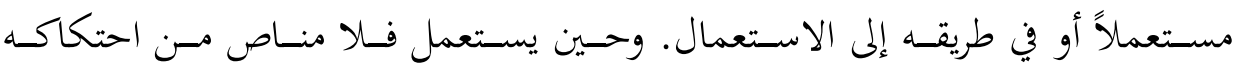

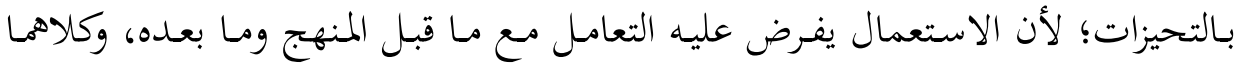
متحيز

وإذا نظرنا إلى إمكانات الوصل والفصل من زاوية المذهب يتبين أنَّ اعتبار الاستنباط

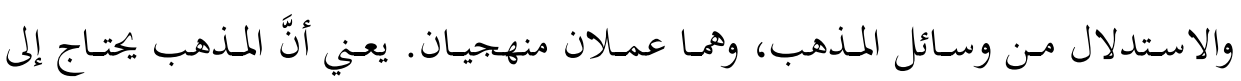
المنهج، ويوحي بأن المذهب والمنهج في جزئهما المتعلق بالاستنباط والاستدلال متطابقان ونان.

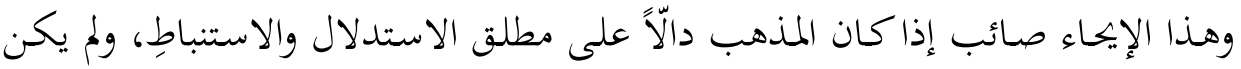

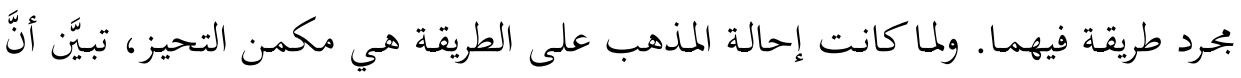

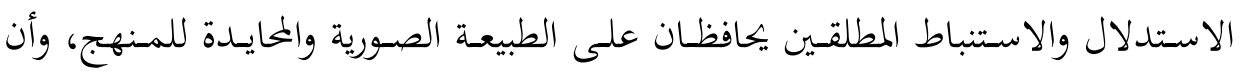

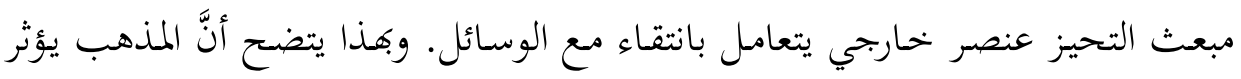

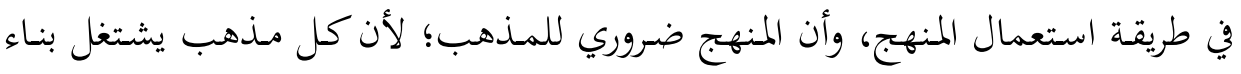
على خطوات منهجية.

وهناك وجه آخر من علاقة المذهب بالمنهج يكشفه النظر في المذهب بوصفه معتقداً

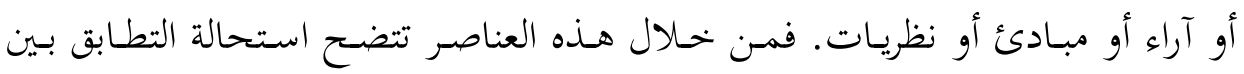

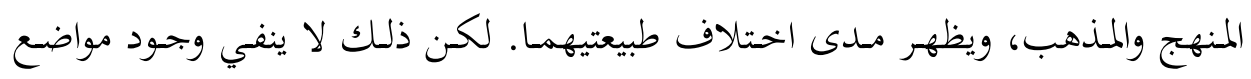

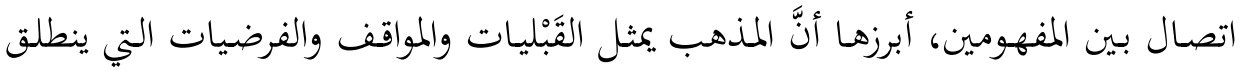

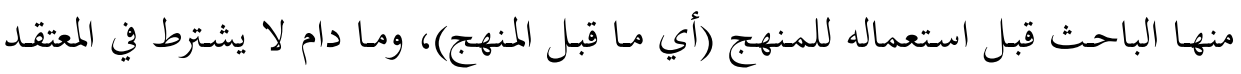

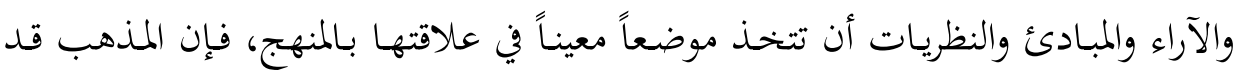

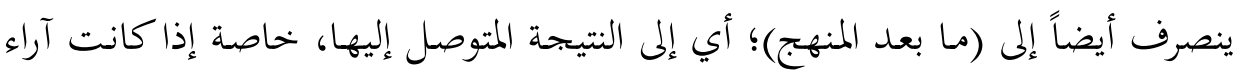

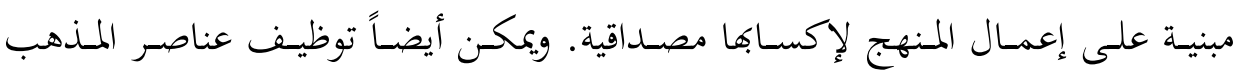

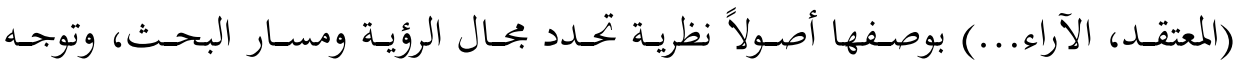
الباحث أثناء استعماله للمنهج. وإذاكان الشكلان الأول والثاني مـن أشكال الاتصـال؛ أي الخـاص بما قبل المنهج

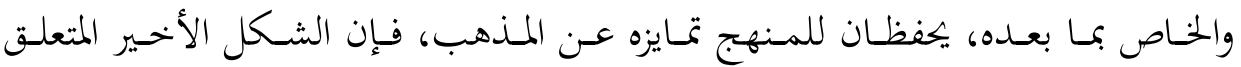


بالأصول النظرية يغيب فيه التمايز؛ لأن المنهج فيه "يرتبط بعناصر فلسفة كامنة، وهذه

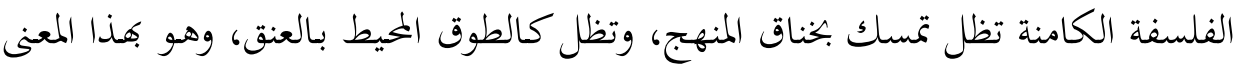

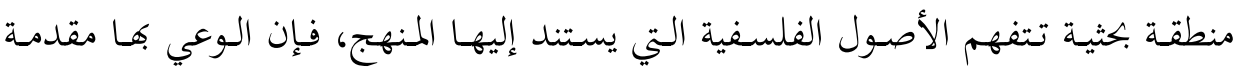

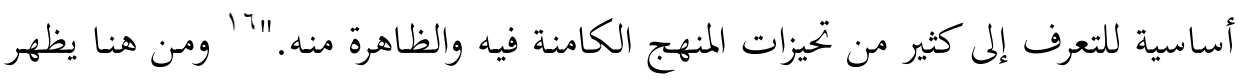

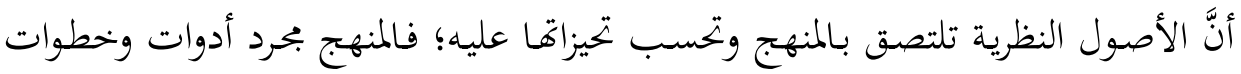

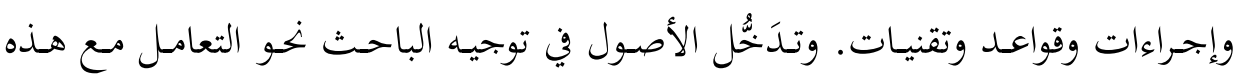
الوسائل بانتقائية يعكس تحيز الأصول لا تحيز الوسائل.

ومن خحلال ما كشفت عنه المقارنة من إمكانات للفصل والوصل لا يتبين أنَّ المنهج

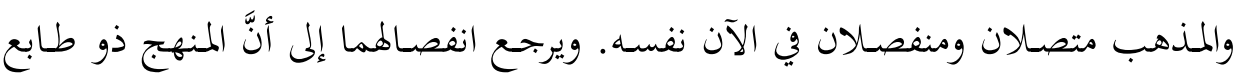

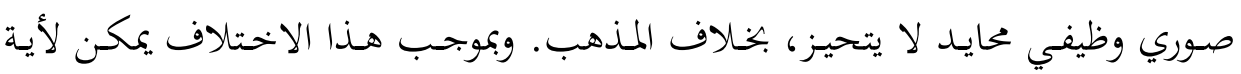

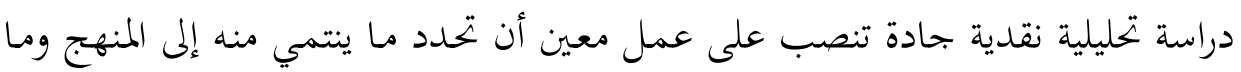

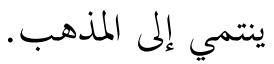

وأما الاتصال بين المنهج والمذهب فراجع إلى أنَّ أحدهما لا ينفك عن الآخر؛ فلا بدّ

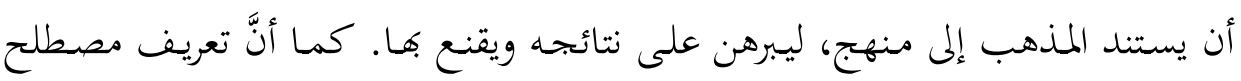

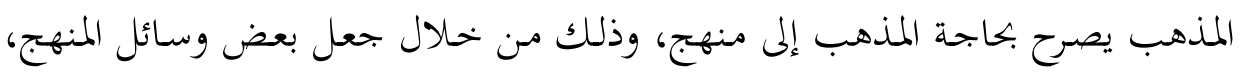

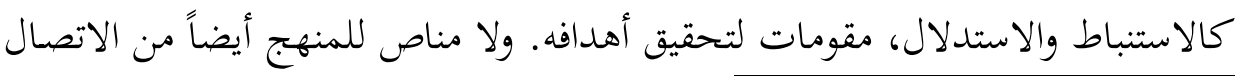

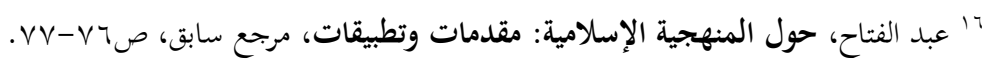

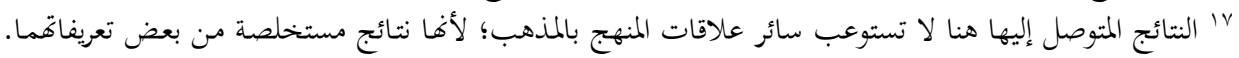

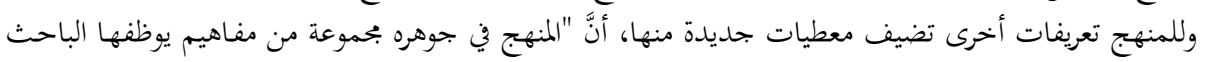

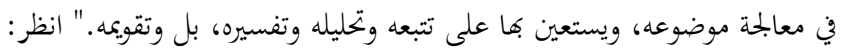

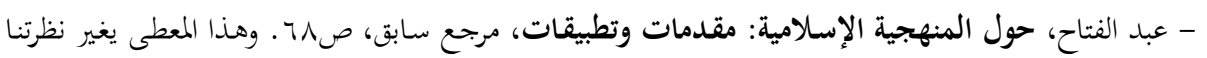

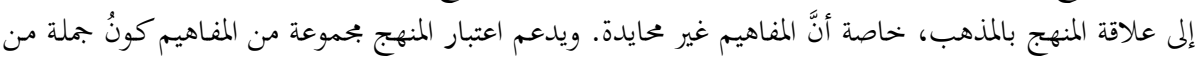

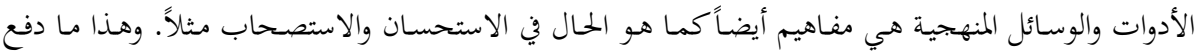

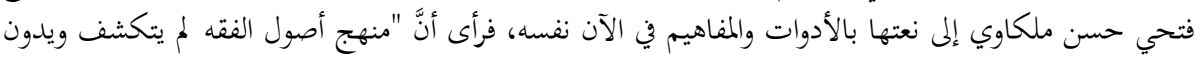

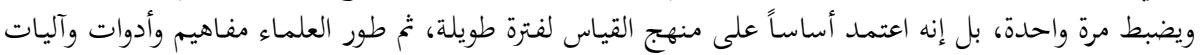

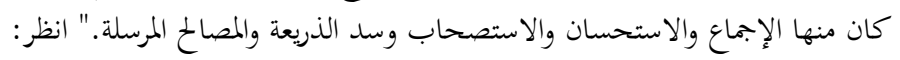

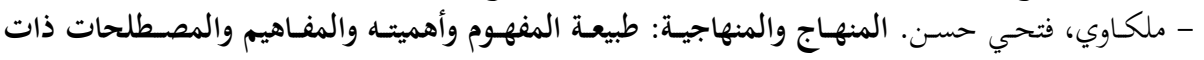

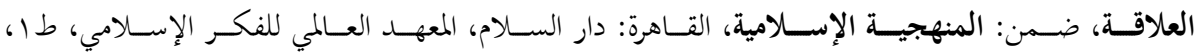


بالمذهب؛ إذ يستحيل أن ينطلق المنهج من فراغ، ويشتغل في فراغ ويصل إلى فراغ، بل لا

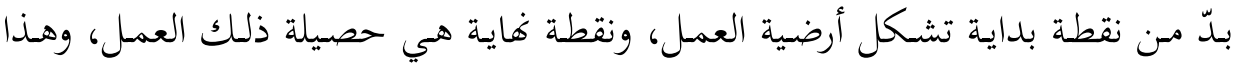
مبعث التحيز.

\section{ب. الاخــلاف في مؤشـر الغايسة وأثره في الفصـل والوصـل بـين "المسنهج"

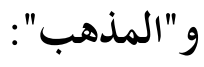

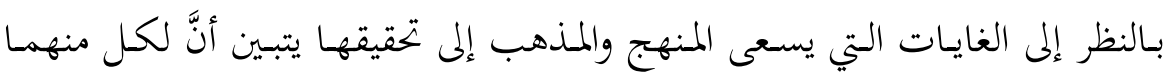

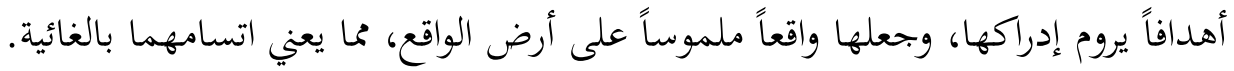
ويظهر من مقارنة المنهج بالمذهب حسب مؤشر الغاية أفما منفصلان نظراً لتباين

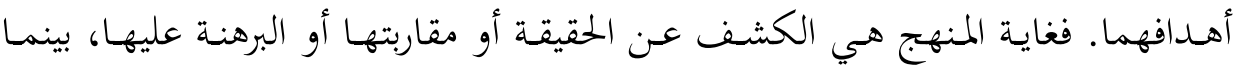

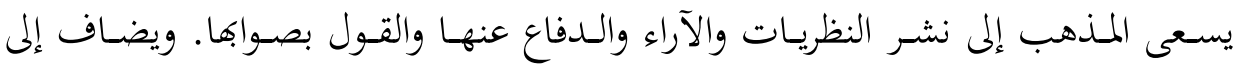

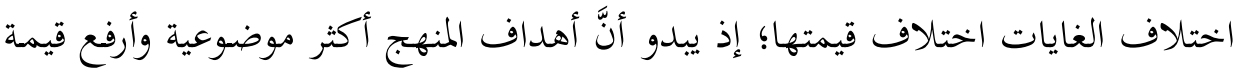

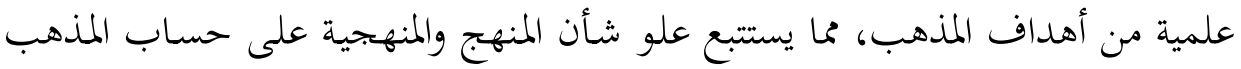

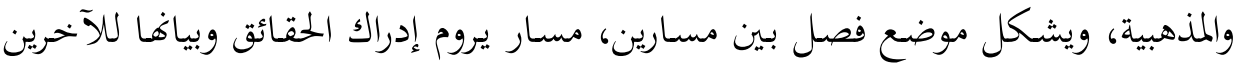

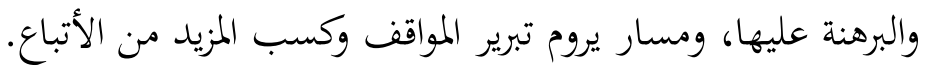

غير أنَّ الاختلاف بين غايات المنهج والمذهب لا ينبغي أن يحجب مواضع الوصل

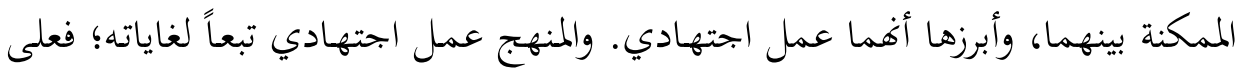

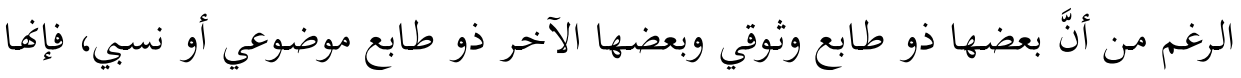

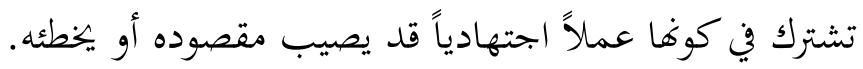

وأما المذهب فارتباطه بالاجتهاد ظاهر؛ فهو بمعناه الاصطلاحي الفقهي ذو غاية

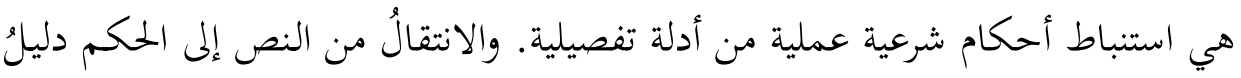

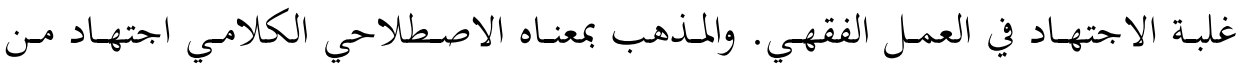

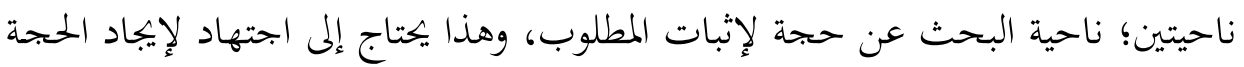

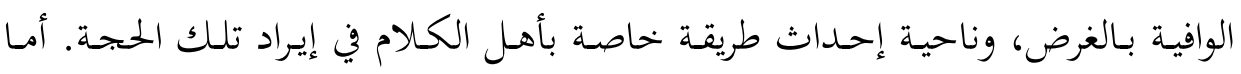


المذهب بمعناه المفهومي فيلتقي مع معنى الاجتهاد في احتماله للصواب والخطأ، وإمكان

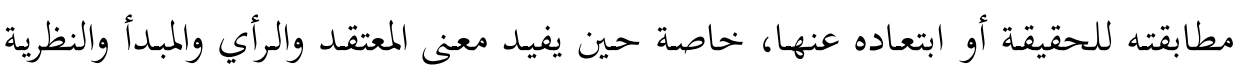
وما شابهه.

يفتح هـا التشـابه بين المنهج والمـذهب طريق البحتث عن مواضع الوصل بينهما،

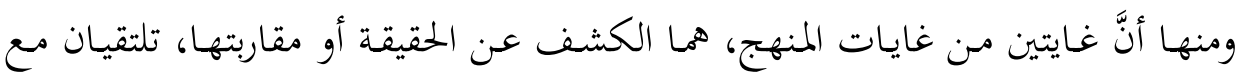

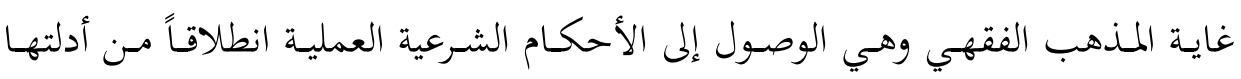

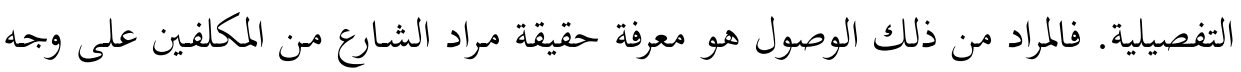

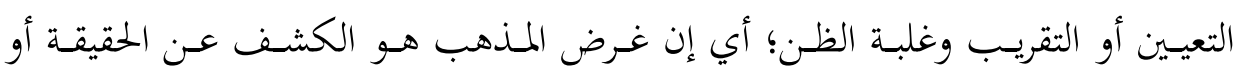
مقاربتها في بحال الفقه.

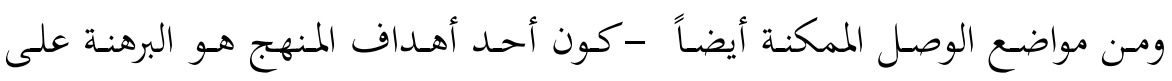

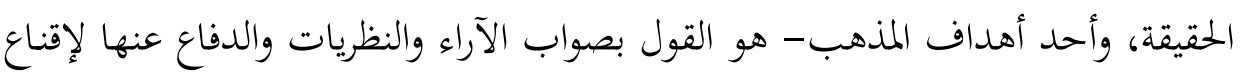

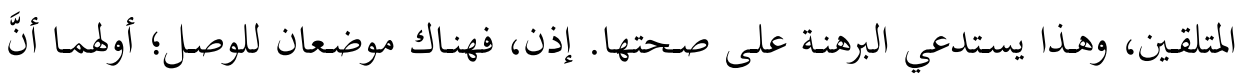

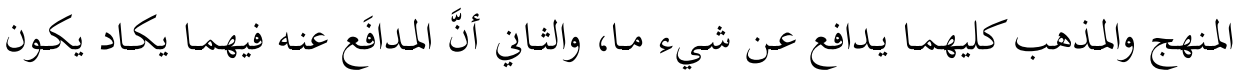

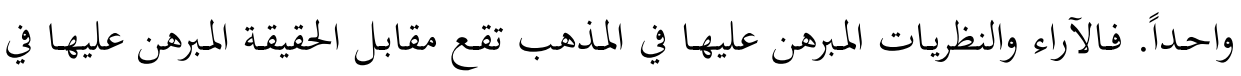

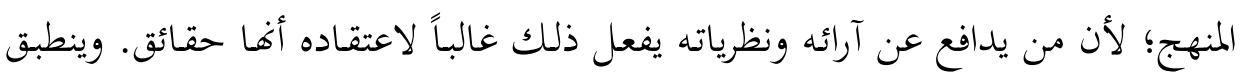

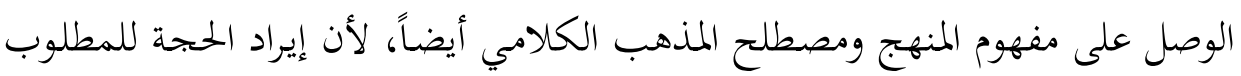

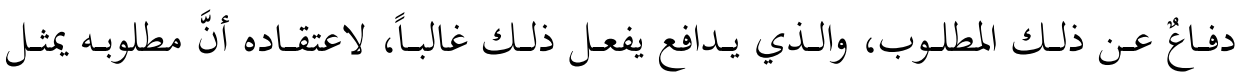
الحقيقة.

وومن خـلال مـا كشـفت عنـه المقارنـة مـن إمكانـات للفصـل والوصـل بـين المـنهج والمذهب بحسب مؤشر الغاية، يتبين أنَّ ما يفصل بينهما هو سعي المنهج إلى تحقيق أكبا أكبر

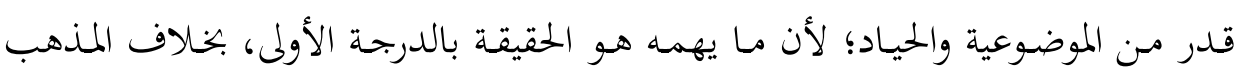

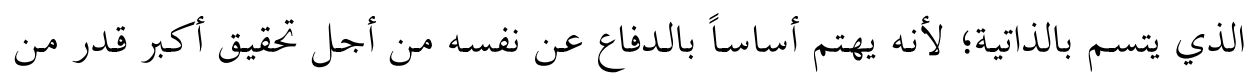

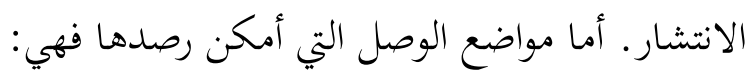
- إنَّ كلًّ من المنهج والمذهب اجتهاد. 
- إنَّ غاية المنهج، المتمثلة في كشف الحقيقة أو مقاربتها، تلتقي مع غاية المذهب الفقهي التي تؤول إلى معنى كشف الحقيقة أو مقاربتها في المحال الفقهي. - إنَّ غايـة المـنهج المتمثلـة في البرهنـة على الحقيقــة تلتقي مـع معنيـين مـن معـاني

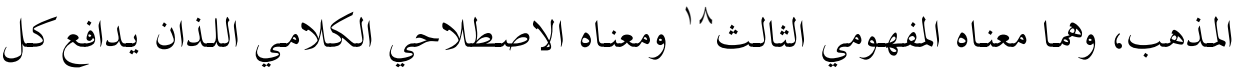
منهما بطريقته عما يراه هو الحقيقة.

\section{ت. الاختلالف في مؤشر المنظومـة وأثره في الفصل والوصل بين "المـنهج"}

إذاكان مؤشر الغاية يضمن قصدية المنهج والمـذهب، فإنان مؤشر المنظومـة يضـمن

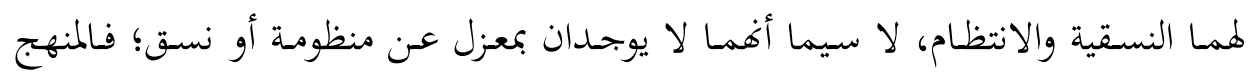

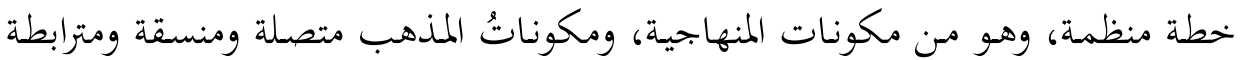

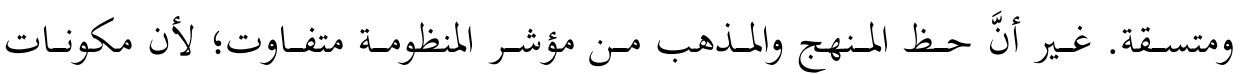

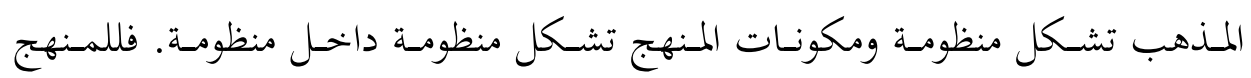

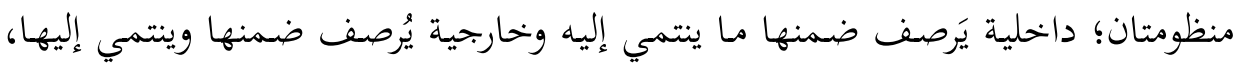

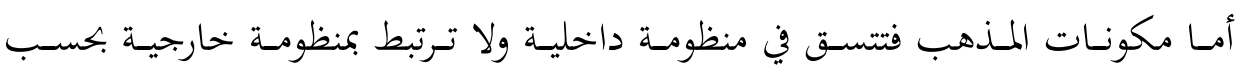
التعريفات المدروسة للمذهب.

تستخلص المنظومة الداخلية للمنهج من تعريفه؛ فهو "خطة منظمة لعدة عمليات ذهنية أو حسية"؛ أي إنه عمل يجمع في صعيد واحد بحموعة من العمليات، لتنتظم في

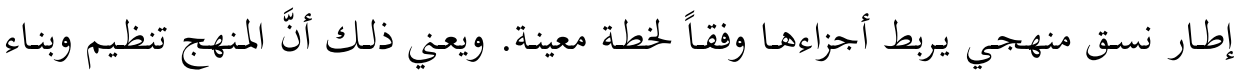

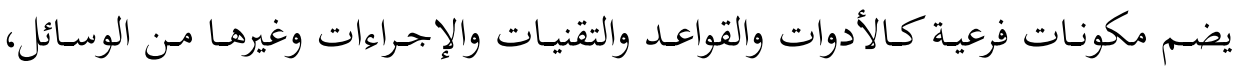

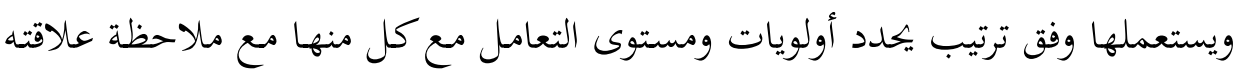
بالآخر.

أمـا المنظومـة الداخلية للمذهبب فوصف المنظومة حاضر فيها؛ لأن مفهوم المنظومة

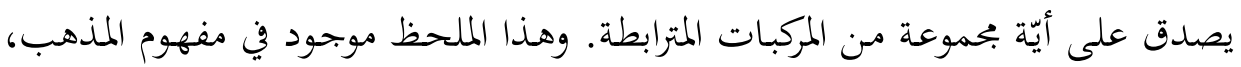


فقد نُعتت مكوناته بالاتصال والترابط والتنسيق والاتساق. ويؤكد ذلك كونُ المذهبب يبني الآراء والمبادئ والنظريات مع تنظيمها وتركيبها على نهو يجعلها متصلة ومترابطة، إما لأغها

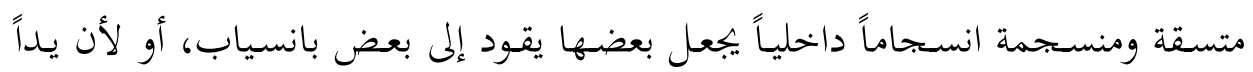
خارجية قامت بتنسيقها لضمان انسجامها. ويتميز المنهج عن المذهب بانتمائه إلى منظومة خارجية أكبر هي منظومة المنهاجية التي ينتظم في إطارها ويشكل أحد عناصرها. وبخلاف ما يظهر من أنَّا المنهج والمنهاجية يجيالان على مدلول واحد، فإن جعل المنهج من مكونات المنهاجية يعني أهما مفهومان متمايزان. ويتحدد موقع المنهج من المنهاجية بالنظر إلى أها "علم دراسة الطرائق وتكوينها

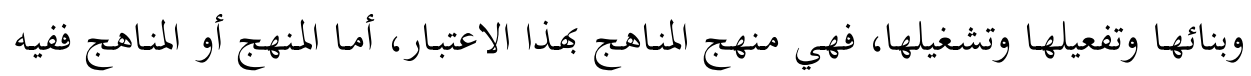

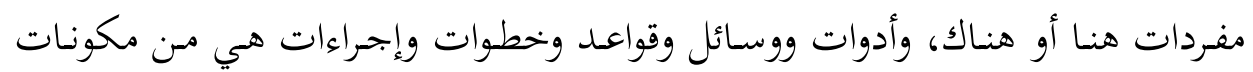

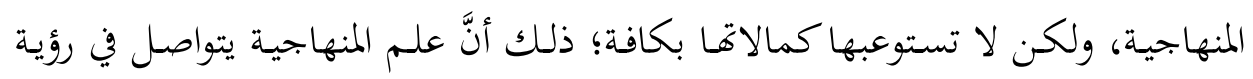
فيما قبل المنهج وفيما بعد المنهج، في سياق واصل ورابط بـين هذه المنظومـة والعناصر

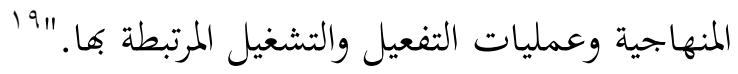

وفي إطلار تحديـد مواضـع الفصل والوصل بـين المـنهج والمـذهب بحسـب العلاقـات

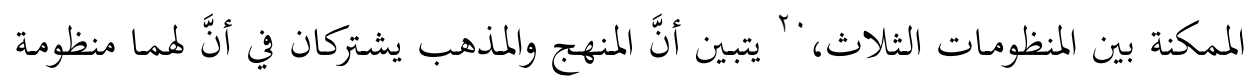
داخلية، وأن المنهج ينفرد بالانتماء إلى منظومة خارجية. وقد يفهم من ذلك أنكات أنَّ المنظومة

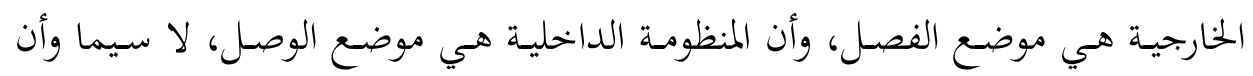

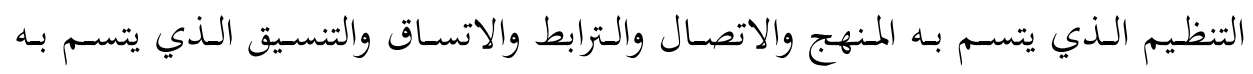
المذهب سمات متقاربة.

غير أنَّ طبيعة المنظومات الثلاث تجعل علاقة المنهج والمذهبب أعقد من هذا الفهم السطحي، فتقارب المنظومتين الداخليتين للمنهج والمذهب لا يعني تطابقهما، بل بينهما

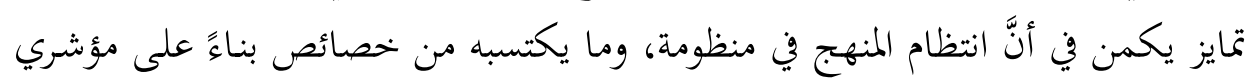
19 19 عبد الفتاح، سيف الدين. المنهجية وأدواتها من منظور إسلامي، ضمن: المنهجية الإسلامية، مرجع سابق، ·" أي المنظومتين الداخلية والخارجية للمنهج، والمنظومة الداخلية للمذهب. 
الوسيلة والغايـة، يـوفران له ضـمانات ليكون سليماً. ومـن أسباب عـدم سـلامة المنهج

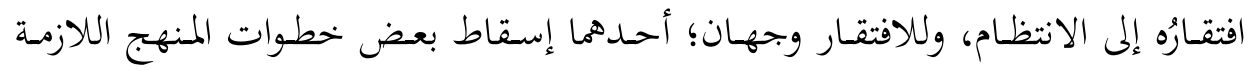

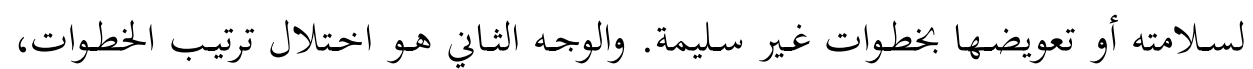
واستعمال الوسائل بخلاف مقتضى سلّم الأولويات.

أما المذهب فانتظام مكوناته؛ (أي الآراء والمبادئ والنظريات) لا يضمن صوابه. فقد تنتظم هذه المكونات، ولكنها قد بتحانب الصواب، كأن تكون غير صحيحة ولا يقينية.

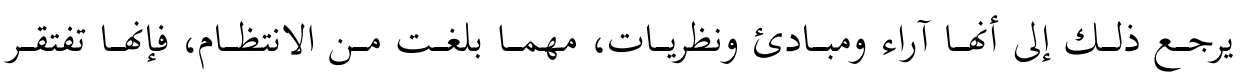

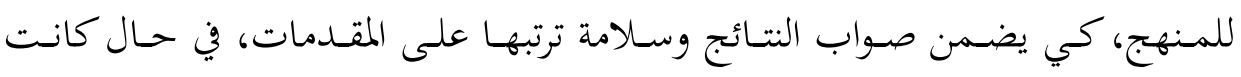

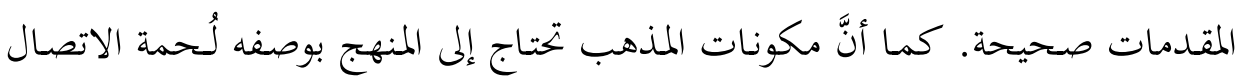

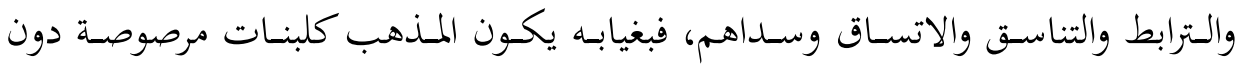

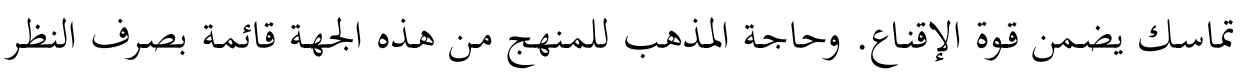

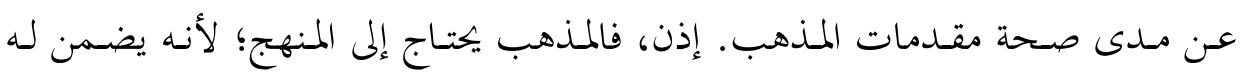
قاعدة صلبة يبني عليها نتائجه ويقنع بصحتها. وتكرس المنظومة الخارجية للمنهج (المنهاجية) اختلافه عن المذهب. ولا مانع مبدئياً

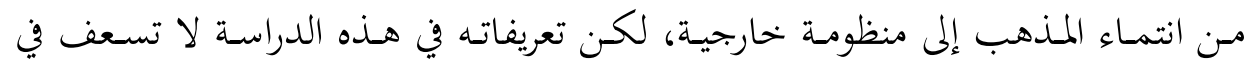
تأكيد ذلك. وفي انتظار الاستقراء يدل افتقار المذهب إلى منظومة خحارجية على حاجته

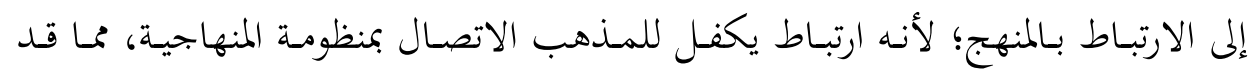
يكسب نتائج المذهب مصداقية، ويفتح له آفاق الانتقال من منظومة معزولة إلى منظومة تحتويها منظومة أكبر.

إذن، فالمـذهب يحتاج إلى المنهج مـتين؛ مـرة لكون المنهج قاعـدة صلبة يبني عليها المذذهب نتائجـه ويضـمن الإقناع بصحتها، ومرة لكـون المنهج ينتمي إلى منظومـة أكسبر

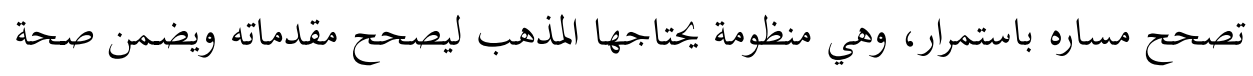

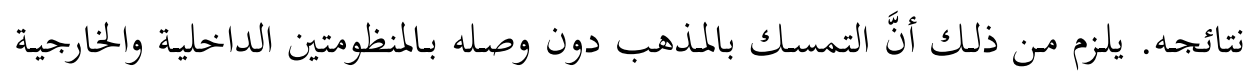
للمنهج هو مذهبية مذمومة ومتعصبة. 
وحسين ينفصـل المـذهب عـن المنظومـة الداخليـة للمـنهج لا تقـوم مكوناتـه الفرعيـة

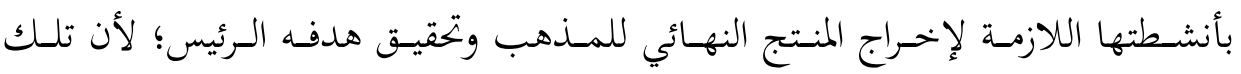

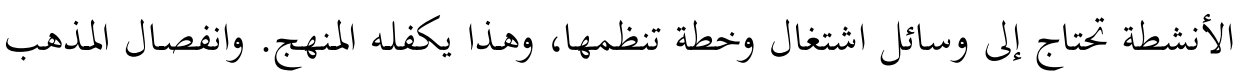

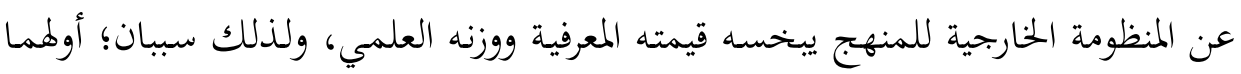
افتقار مكونات المذهب إلى الصحة، في حسين تضمن المنهاجية صحة مقدمات وندية ونتائج

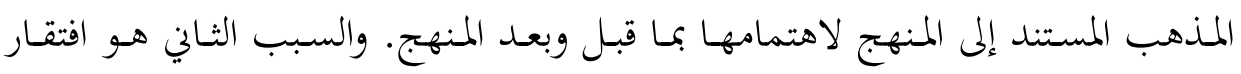

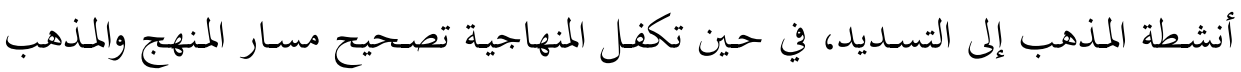
المستند إليه لكوفها علم المناهج.

ث. الاخـتلاف في مؤشـر المجـال وأثره في الفصـل والوصل بـين "المسنهج"

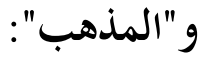

تفيد المقارنة بين بحالي المنهج والمذهبب وجودً اختلافات وائتلافات بينهما، سببها عدم الاتفاق في تحديد بجالات اشتغال كل مـ المنهج والمذهبب. ولكل ذلك وحت تأثنيره في

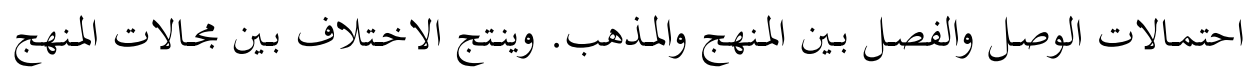

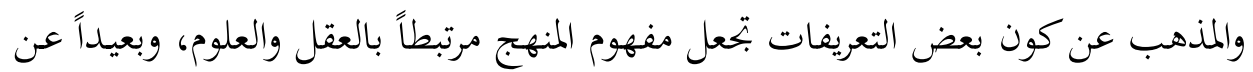

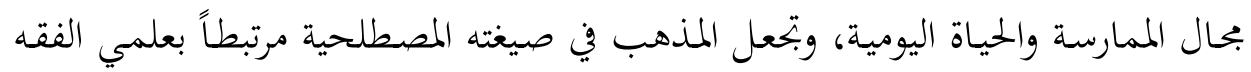

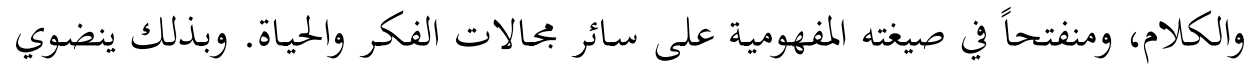

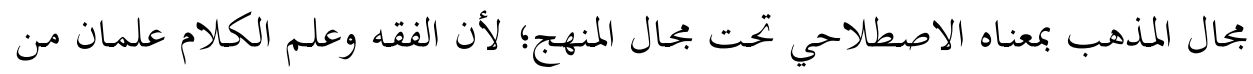

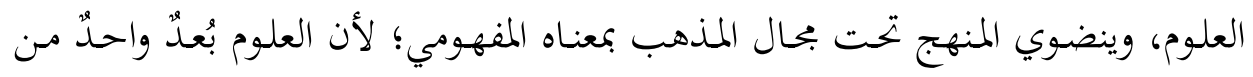

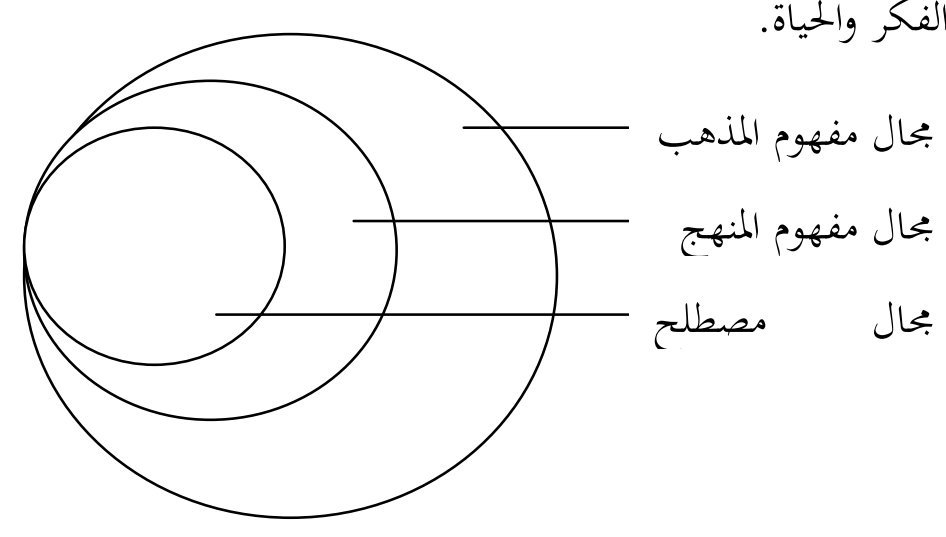
أبعاد الفكر والحياة. 


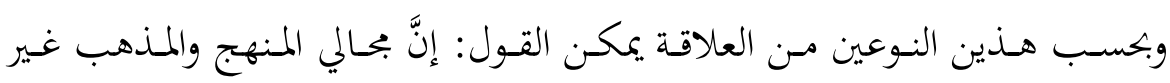

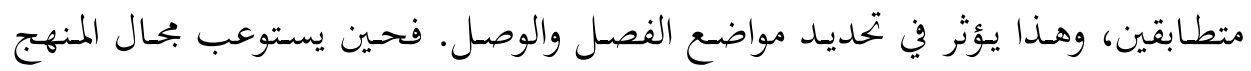

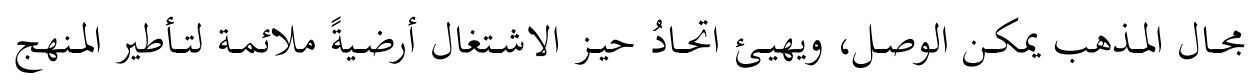

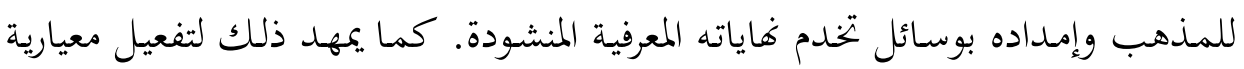

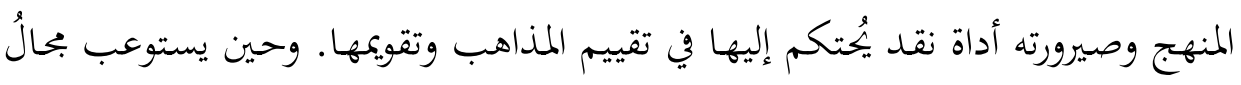

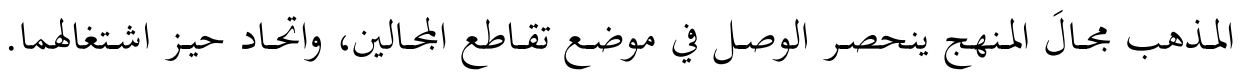

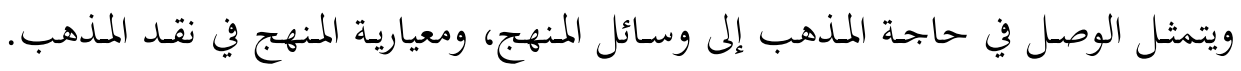

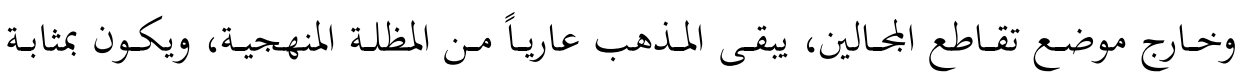
خلفيات فلسفية لا سبيل إلى التحقق من صحتها وتطبيق المنهج عليها. وأما الائتلاف بين بحالات المنهج والمذهب فينتج عن توسيع بعض التعريفات بحال

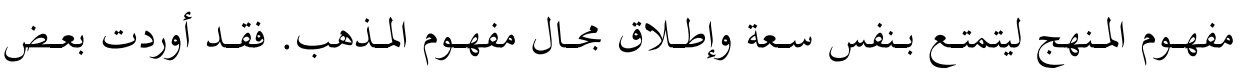

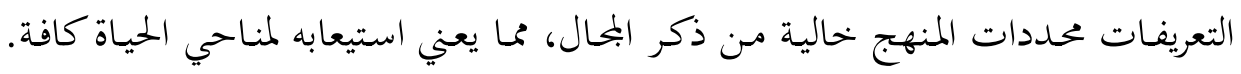

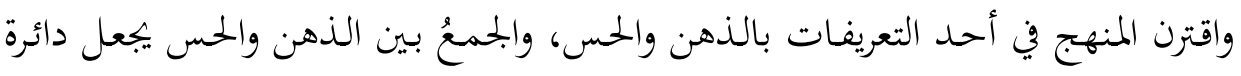

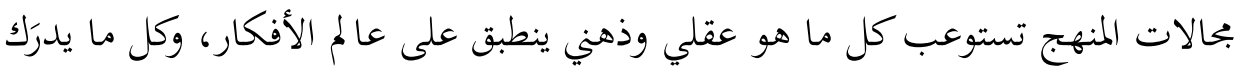

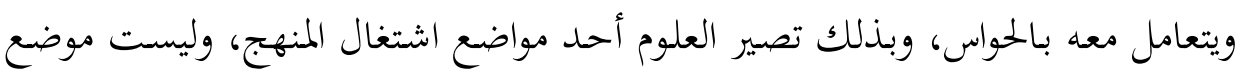
اشتغاله الوحيد، ويصير المنهج مستوعباً مناحي الحياة كافة.

ويترجح المعنى الثـاني الموسع لمحال المنهج على المعنى الأول الذي يجصـره في بحال

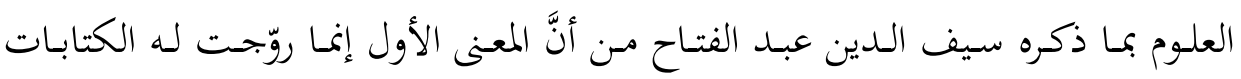

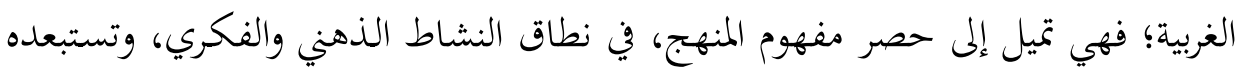

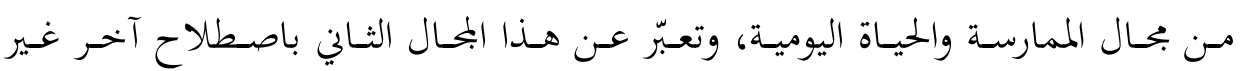

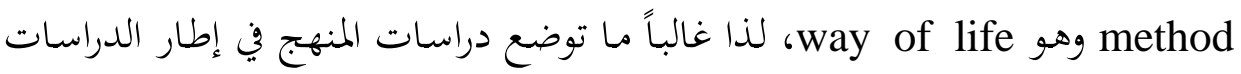
النظرية أو الكتابات الفلسفية. بينما تؤكد معظم كتابات التراث الإسلامي المهتمة بالمنهاتجاج

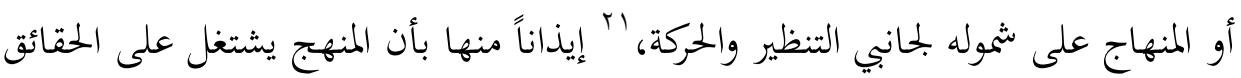
المعرفية المختلفة في بحالاتحا المتعددة. 
ولماكانـت هـذه الدراسـة تعـنى بمقاربـة المنهجيـة والمذهبيـة في البحـال التـاولي العـبي

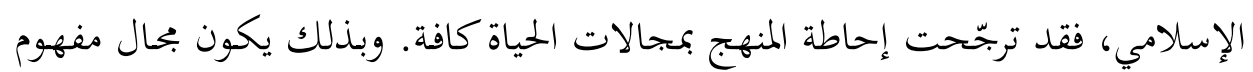

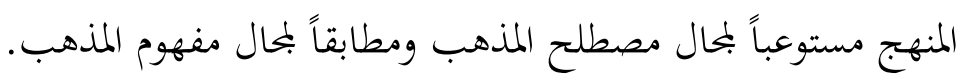

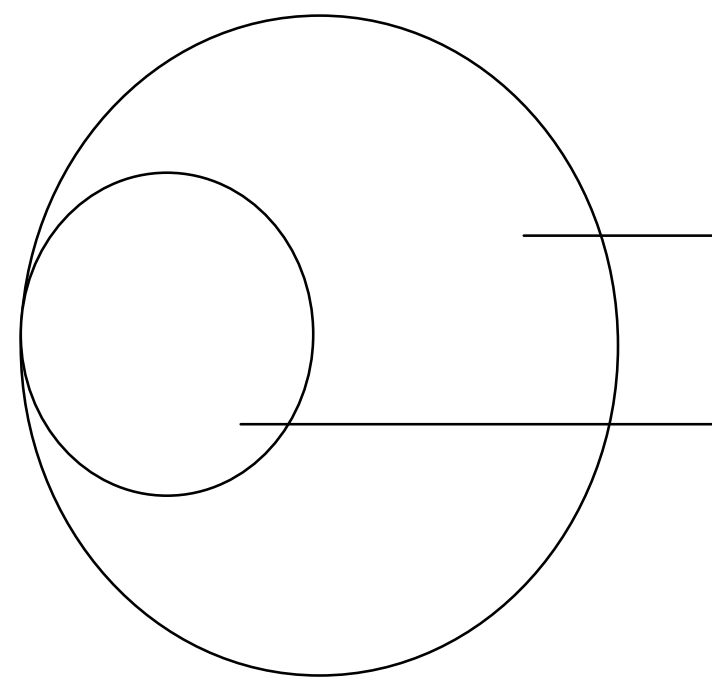

بحال مفهومي المنهج والمذهب بحال مصطلح المذهب

ويؤثر ائتلاف بحالات المنهج والمذهب في إمكانات الفصل والوصل بينهما. فمطابقة

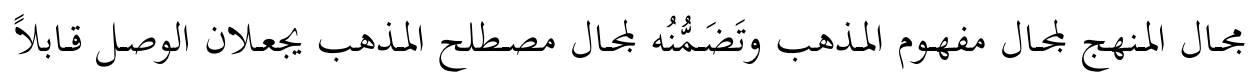
ليكون تامـاً. وإذا أضيف إلى ذلك ارتبـاط البمالات بمنـاحي الحياة كافة تبين أنَّ الوصل قابل للاستمرار باستمرار الحياة وتطورها.

ويُرَدُّ تمـام الوصل إلى أنَّ اتحـاد حيز الاشتغال يضـمن لكل مـذهب منهجـاً يقابله،

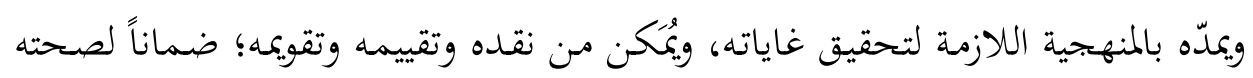

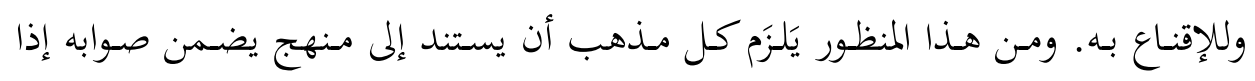
كانت منطلقاته صحيحة، ويضمن تصويبه إذا كانت منطلقاته فاسدة.

أما استمرار الوصل بين المنهج والمذهب فتابع لتطور الحياة باستمرار، فارتباط المنهج

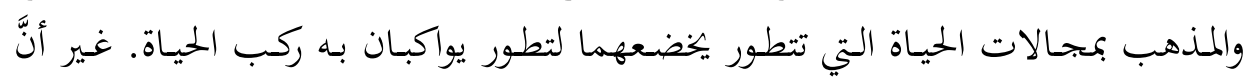

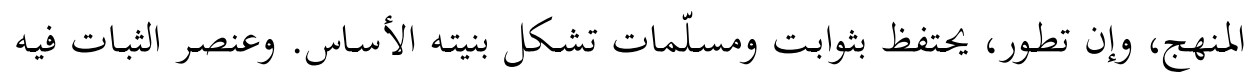


إضافة إلى قدرته على مواكبة المستجدات يمكنانه من ضبط تطورات العلاقة بين الذات الباحثة، وموضوعات البحث التي تطرقها المذاهب.

ثانياً: حظ "المنهج" و "المذهب" من النضج وأثثه في الوصل والفصل بينهما: 1 ـ حظ "المنهج" و"المذهب" من النضج:

النضج معيار إضافي لقياس اصطلاحية المفردات؛ فإذا كان اللفظ غير تام النضج

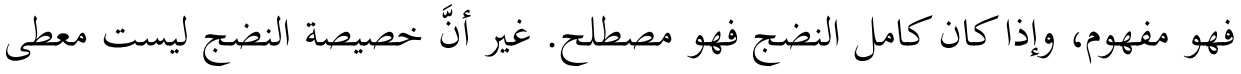

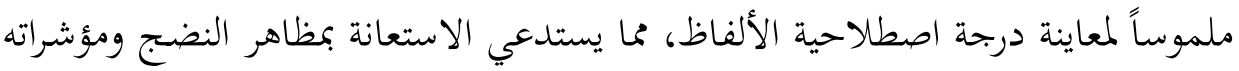

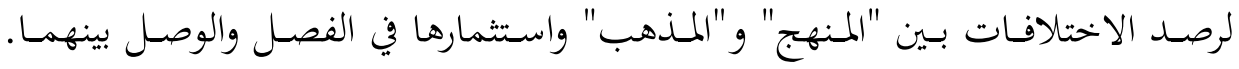

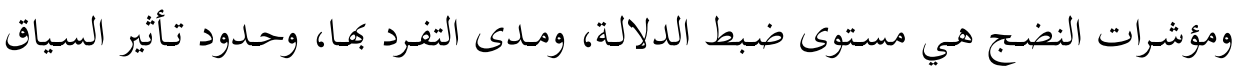
فيـا

\section{أ. مؤشر الضبط الدلالي وفائدته في الوصل والفصل:}

بموجب الضبط الدلالي يقع المصطلح في أعلى درجات الانضباط؛ فتعريفه لا يقبل

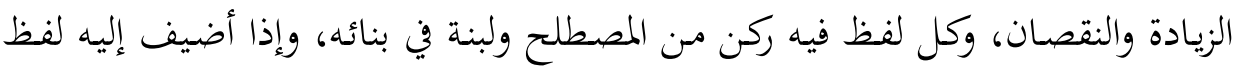

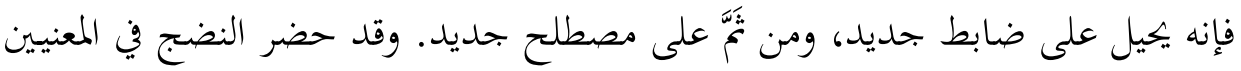

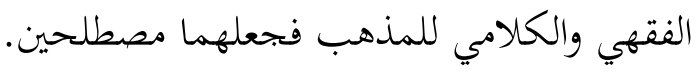
يكضـر النضـج في تكسوين المفهوم بشـكل أخسف مس حضـوره في تكوين المصطلح،

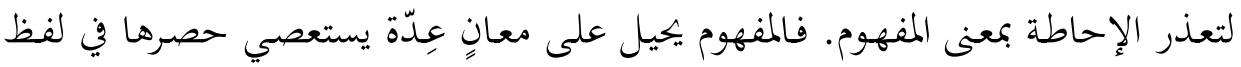

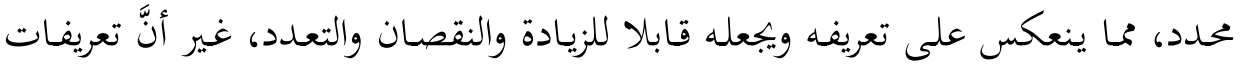
مفهوم معين تلتقي في نقاط مشتركة هي إطاره العام.

إن هذه المعطيات الجحيدة المستفادة من مؤشر الضبط الدلالي لا تضيف إلى معرفتنا

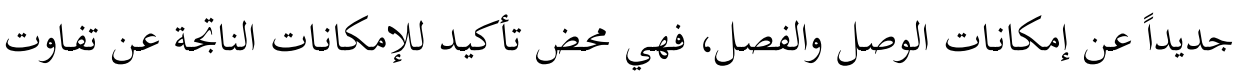




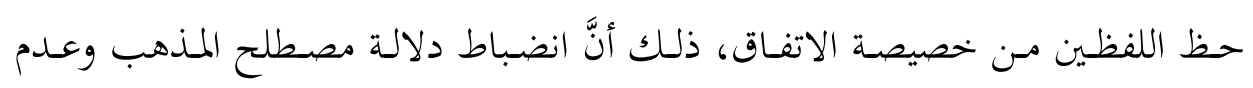
انضباط دلالة مفهومي المنهج والمذهب يؤول إلى القول بعدم الاتفاق في دلالة المفهومين،

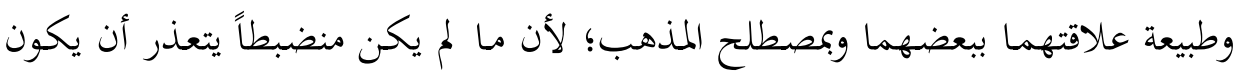

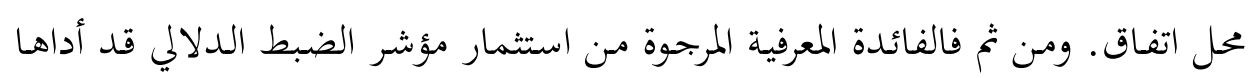
استثمار خصيصة الاتفاق.

\section{ب. مؤشر التفرد الدلالي وفائدته في الوصل والفصل:}

يعني التفرد الدلالي أن يكون المصطلح متفرداً بالدلالة الدقيقة على معناه، فيُستعمل الدّال بإزاء مدلول واحد، ويرفض المصطلح الترادف والاشتراك. وتنطبق هذه المواصفات

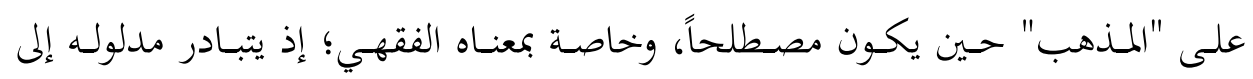
الذهن بمجرد التلفظ به.

يكضـر هـذا المؤشـر في تكـوين المفهوم أقـل مـن حضـوره في تكـوين المصطلح؛ لأن المفهوم يجيل على بحال دلالي عام لا ينحصر في معنى معين. ولا ينفي ذلك دقة دئ دلالة

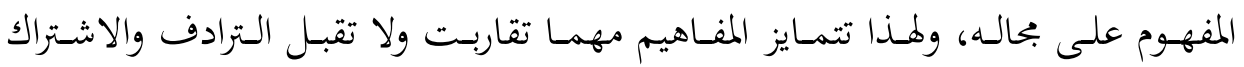

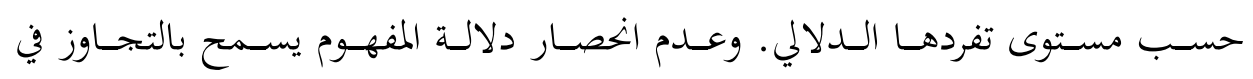
الاستعمال على نحو يوهم بالترادف أو الاشتراك. من هذا المنظور يمكن مقاربة مفهومي

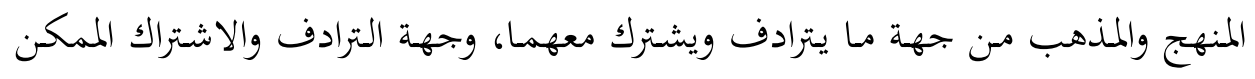
بينهما.

إن الجهة الأولى لن تستثمر في هذه الدراسة؛ لأن بحالها الدقيق ليس هو مؤشر التفرد الدلالي، وإنما هو صورة جزئية أخرى من صور الإشكال المفهومي، لا سيما بالشبكة

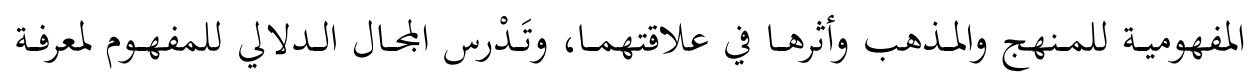
مدى اتساعه واحتمال اختلاطه بغيره.

أمـا الجههـة الثانيـة ففيهـا ينبغـي بحـث علاقـة اللفظـين عـبر بيـان أثـر التجـاوز في

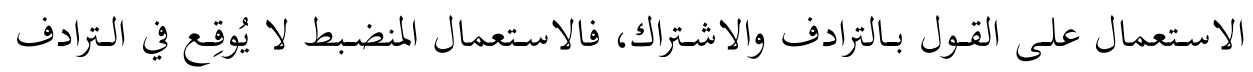


والاشتراك؛ لأنه يحترم كون الأصل في المصطلحات هو تفردها بالدلالة على معنى معين، وكونَ الأصل في المفاهيم هو تفردها بمجالها الدلالي. بَّ وملا كان الترادف والاشتراك نابحين عن التجاوز في الاستعمال، لم يكن الموضع الطبيعي لمناقشة الجهة الثانية هو مؤشر التفرد بالدلالة، بل مؤشر تأثير السياق؛ لأن الاستعمالَ وضعُ للفظٍ في سياق.

\section{ت. مؤشر تأثير السياق وفائدته في الوصل والفصل:}

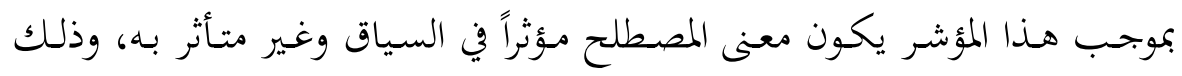

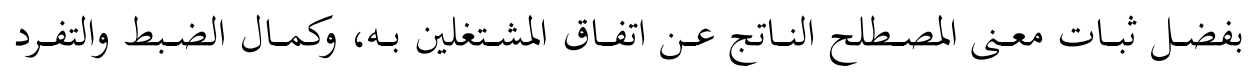

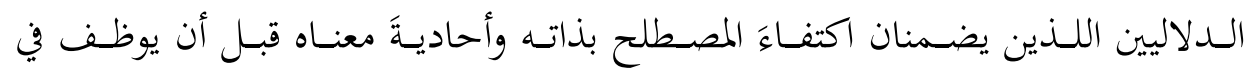
الخطاب، وتأثيره في مبنى النص ومعنى الخطاب. وما دام المذهب يستعمل في الفقه وعلم

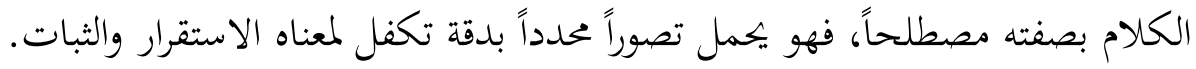
أما المفهوم فإن عدم الاتفاق حوله وقلة ضبطه الدلالي يجعلانه عرضة لتأثير السياق،

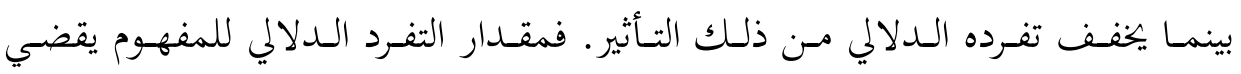

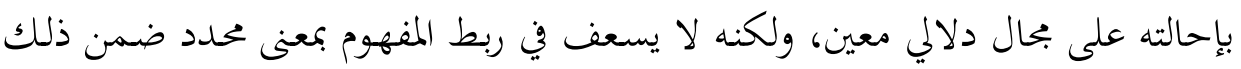
المجال، وبذلك تتعدد استعمالات المفهوم وتتأثر بمفعول السياق تأثراً مفيداً أو مضراً. يؤثر السياق في المفهوم تأثيراً مفيـاً حـين تُستثمر إحالة المفهوم على بجـال دلالي

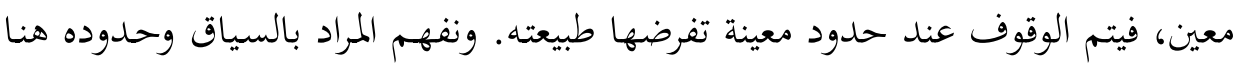

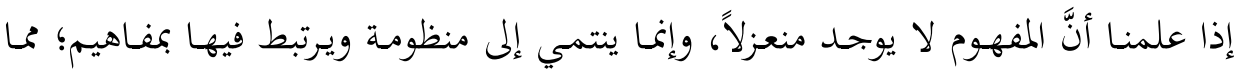

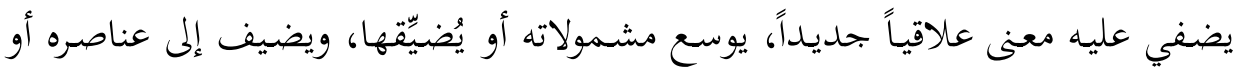

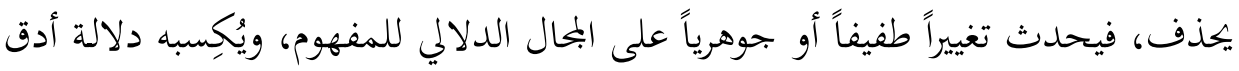
من دلالته قبل الانتظام في سياقه الجحديد.

ويؤثر السياق في المفهوم تأثيراً مضراً حين يُستثمر عدم إحالة المفهوم على معنى

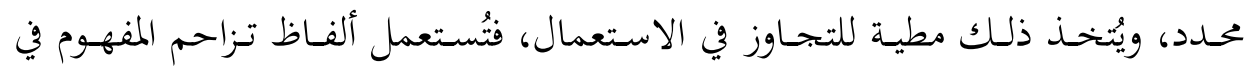
rrr قد يستعمل المنهج والمذهب مترادفين كأن "يقال: منهج الشافعي في الأصول أو منهج المعتزلة في الكلام، ويقصد به المذهب." انظر: المانج ولماهي - ملكاوي، التفكير المنهجي وضرورته، مرجع سابق، صلا ا. 


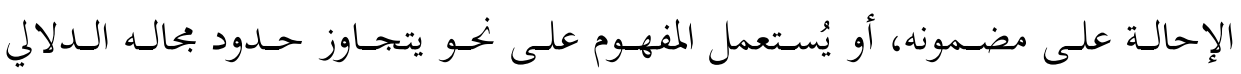

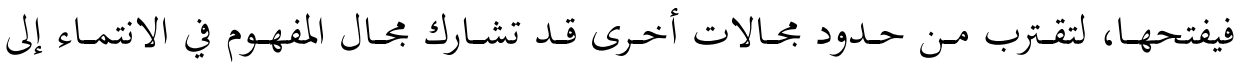

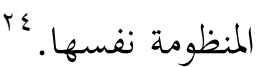

وعلى الرغم مـن أنَّ دراسة المنهج والمذذهب مـن زاوية تأثرهما بالسياق تفتح آفاقاً

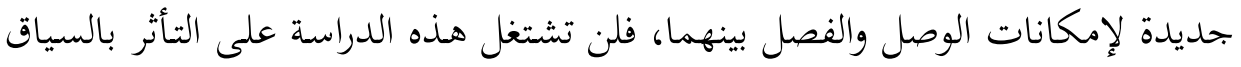

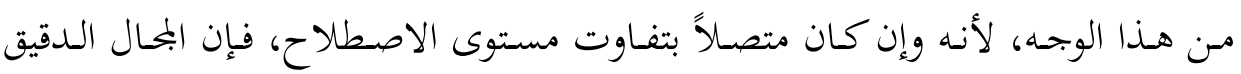

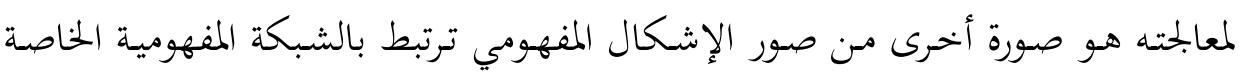
بكل مفهوم.

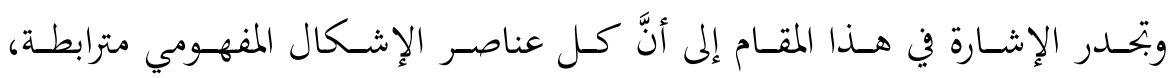

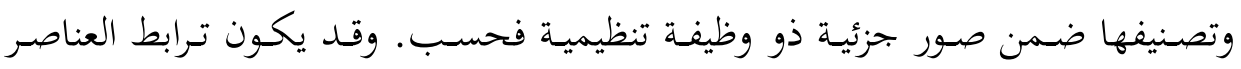

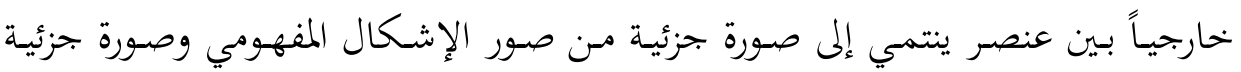

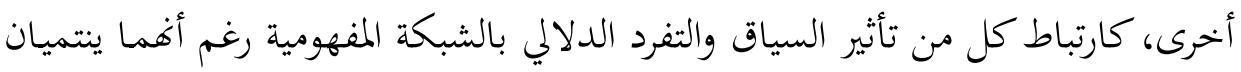

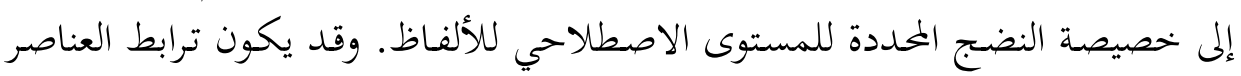

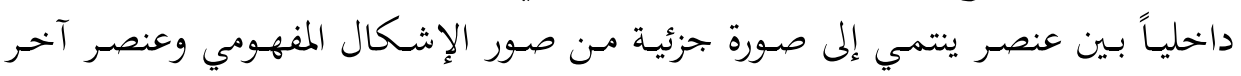

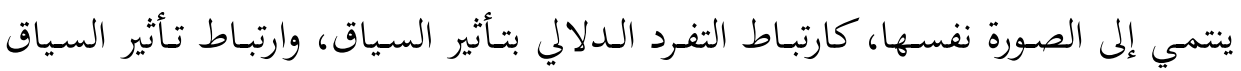

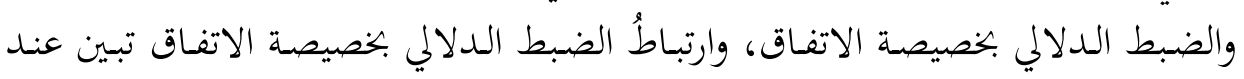

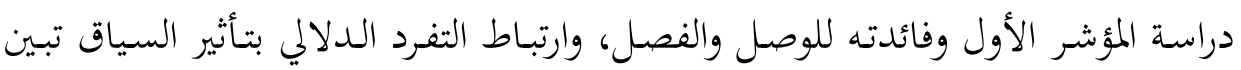

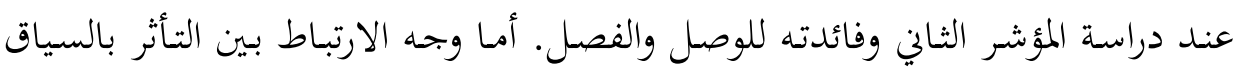

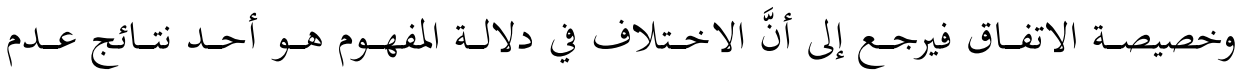

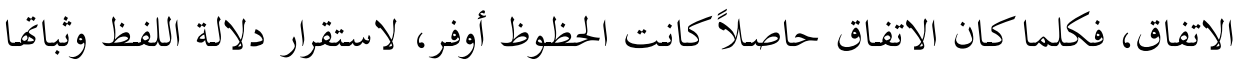
مهما كان السياق الذي وضع فيه اللفظ.

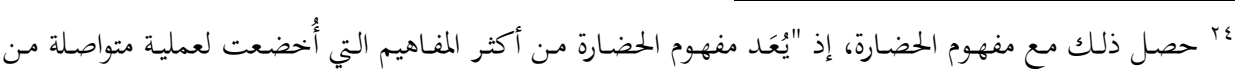

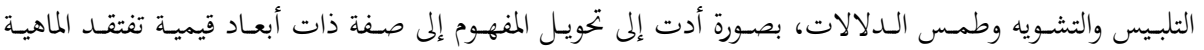

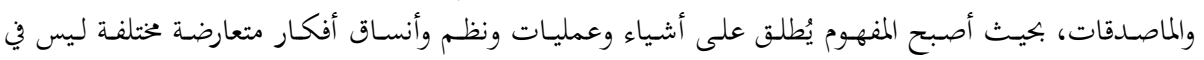

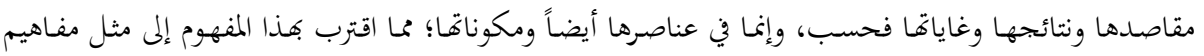

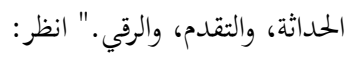

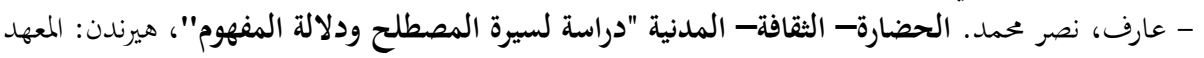

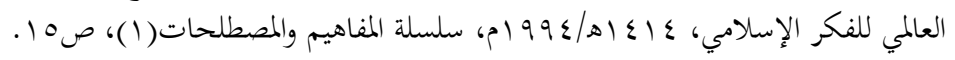


وفيما يلي رسم توضيحي لترابط عناصر الإشكال المفهومي:

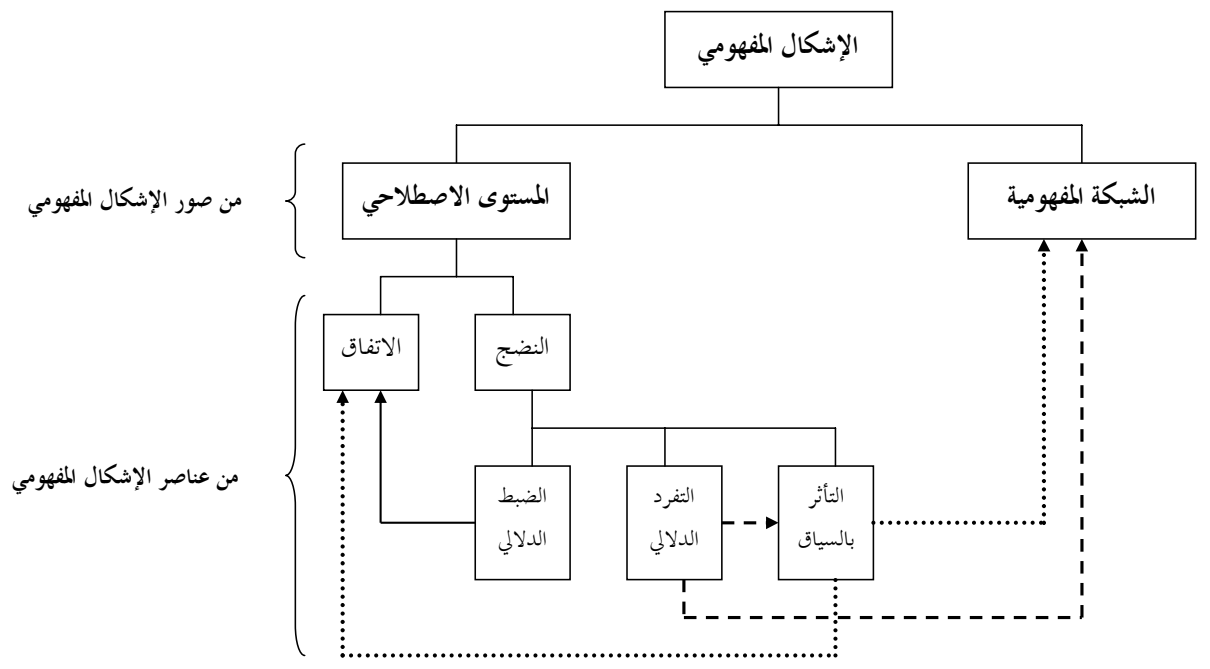

ويمكن دراسة مؤشر التأثر بالسياق مـن وجه آخر يصب في الاختلاف الناتج عن تفـاوت مستوى الاصطلاح، وهـو مـدى استتجابة المـنهج والمـذهب لعلاقتهمـا السياقية

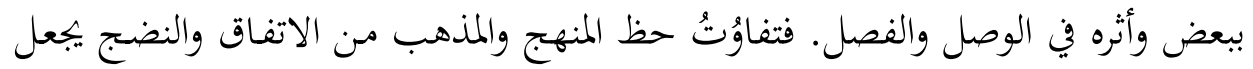

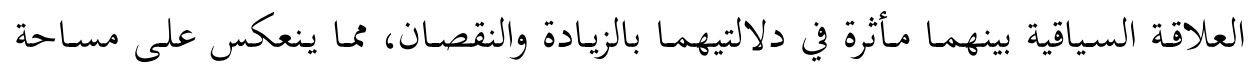

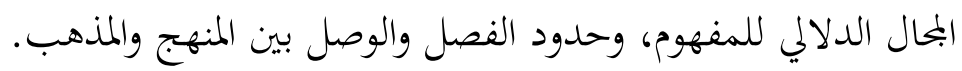
ومن الناحية النظرية، فإمكانات الوصل والفصل النابحة عن استثمار العلاقة السياقية بين المنهج والمذهبب مفيدة؛ فهي إما تؤكد صحة نتائج تحليل تعريفات المنهج والمذهبب بنـاء على حظيهما مـ خصيصة الاتفـاق، أو تثبـت خطأ تلك النتائج، أو تفتح البحال لإيباد نتائج جديدة.

Y. أثر اسـتجابة المــهج والمـذهب لعلاقتهمـا السـياقية بـبعض في الوصـل

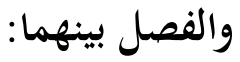

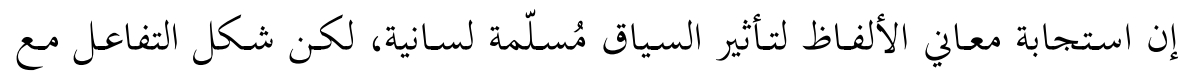
السياق يختلف تبعـاً لطبيعة اللفظ؛ فمستوى استجابة المصطلحات والمفـاهيم لعلاقاتها

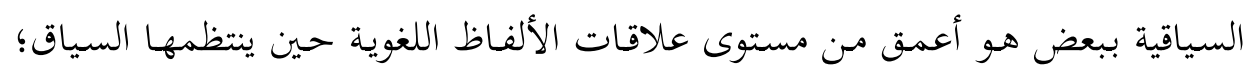


ففيه تحدث علاقات تأثير وتأثر أعقد من التي تربط بين ألفاظ ليست لها حمولة مفهومية أو مصطلحية.

إن تناول المنهج والمذهب من هذه الزاوية ليس دراسة سياقية فحسب، وإنما هو من

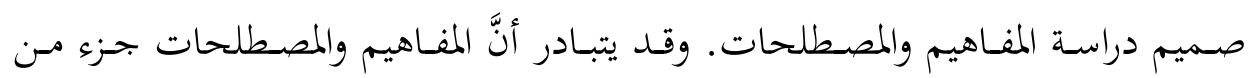

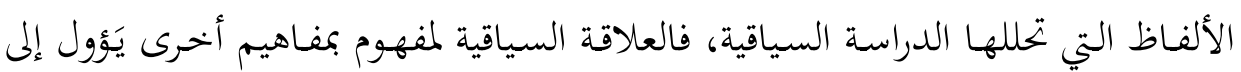
فكرة تأثير السياق على دلالات الألفاظ؛ لأن المفـاهيم الأخرى مـن مكونات السيات السياق. لكن هذه النظرة التي تطمس ملامح خصوصية المقاربة السياقية للمصطلحات ولتحئ والمفاهيم ليست دقيقة؛ لأن السياق مؤشر للتمييز بين المصطلحات والمفـاهيم وتحديد طبيعتها، تلفيا،

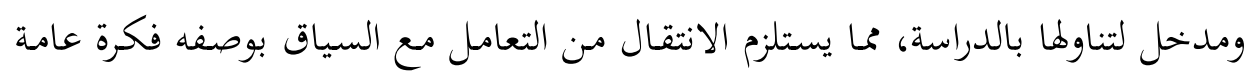

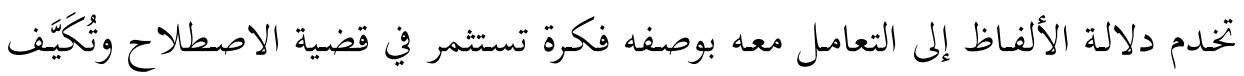

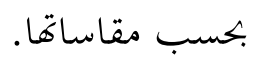

ومن منطلق اختلاف تفاعل المصطلح مع السياق عن تفاعل المفهوم معه، يكون

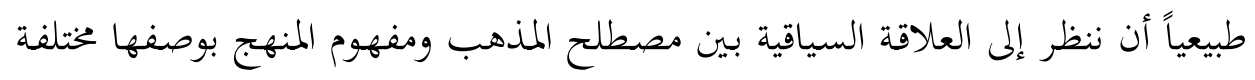

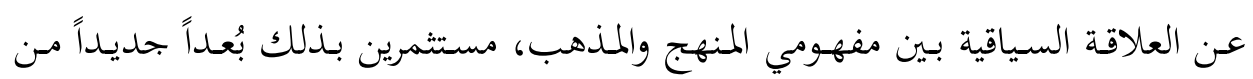

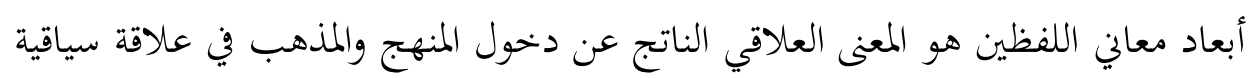

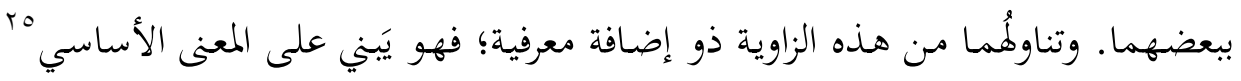

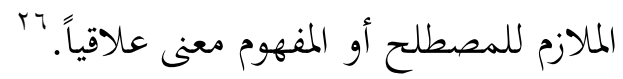

إن مفتاح الوصول إلى المعنى العلاقي هو قياس مدى استجابة "المنهج" و "المذهب"

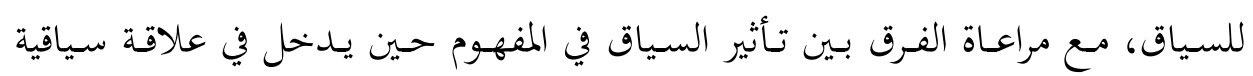
بالمصطلح، وتأثيره فيه حين يدخل في علاقة سياقية بمفهوم آخر.

فحين تربط المفهومَ علاقـة سياقية بمفـاهيم يصسير منتمياً إلى منظومـة تكسبه معنى

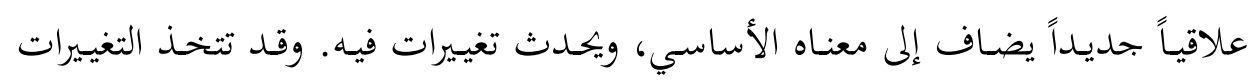

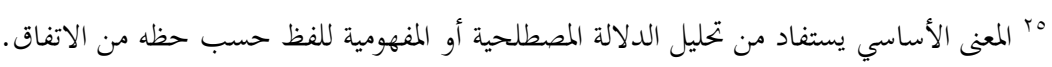

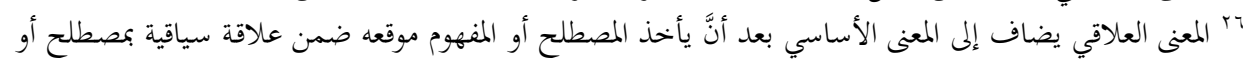
مغهوم غيره. 
أشـكالا عديـدة تحكمهـا خصوصسيات المفــاهيم المترابطـة بعلاقـة سـياقية. وتـؤثر تلـك التغييرات في البحال الدلالي للمفهوم، وتُكِسبه حمولة دلالية أدق من دلالته قبل الانتظام

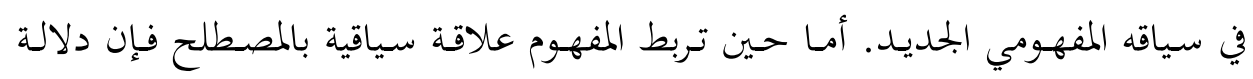

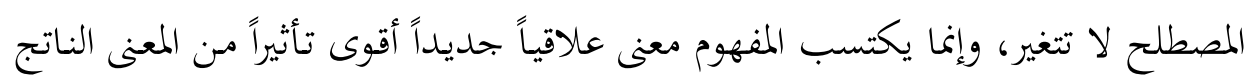
عن الارتباط بين مفهومين. وقوة تأثير المعنى العلاقي (وهي نابعة من قوة الاصطلاح في

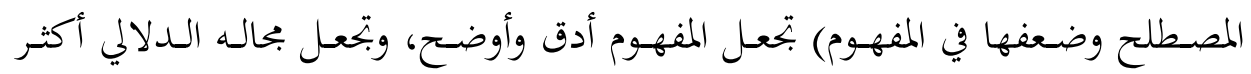
تخصيصاً. وبموجبها أيضاً تؤثر المفاهيم في بعضها، ويؤثر المصطلح في المفهوم ولا يتأثر به. يتبين إذن، أنَّ المفـاهيم تكون متكافئة ومتعادلة فيما بينها، مـن حيـث الانتماء إلى لى مستوى اصـلاحي دون مستوى المصطلح وفوق مستوى اللفظظ اللغوي. أمـا المفهوم

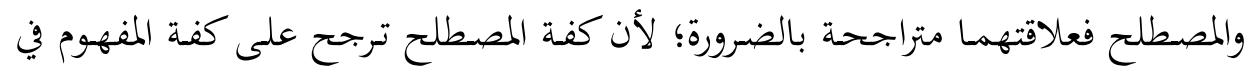
ميزان الاصطلاح.

ويبقى تعادل المفـاهيم والتراجح بين المفـاهيم والمصطلحات حكماً أولياً يحتاج إلى تدقيق، وخحاصة فيما يتعلق بتكافؤ المفاهيم، فهو ليس تامـاً من جهتين؛ جههة أنَّ نقص

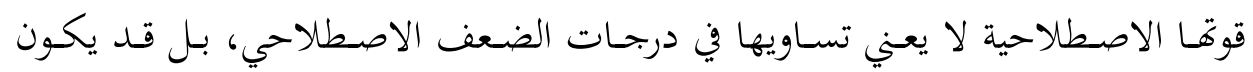

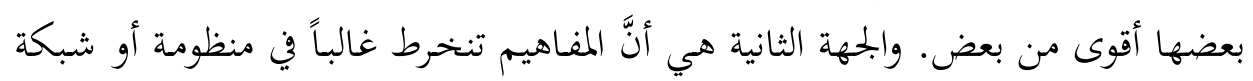

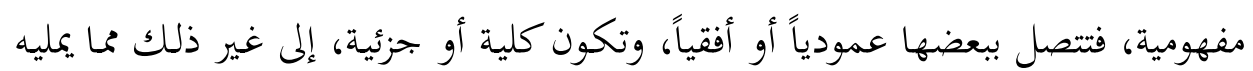
موقع المفهوم ضمن بحاله المعرفي.

ويصـدق الأمـر نفسـهـ على المصــلحات، ولكـن مـن الجهــة الثانيـة فحسـب؛

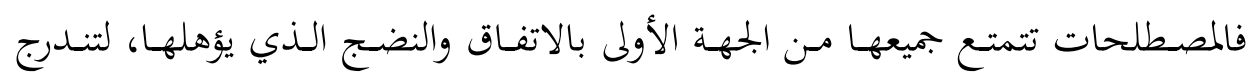

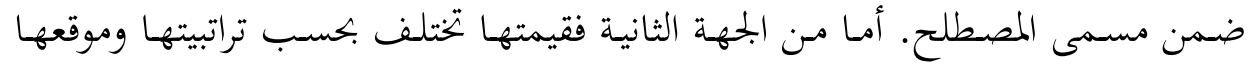

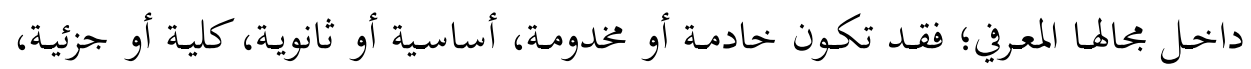
أصلية أو فرعية، وقد ترتبط ببعضها عمودياً أو أفقياً.

إذن، فكفـة المصـطلح لا تـرجح على كفــة المفهـوم إلا باعتبـار تفــاوت مسـتوى

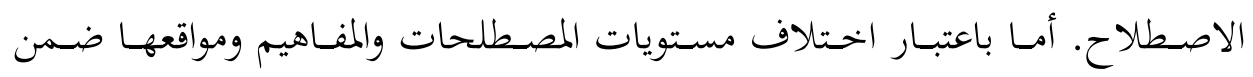


بحالاتها المعرفية، فالباب يبقى مفتوحاً أمام إمكانات من العلاقة بين المصطلح والمفهوم

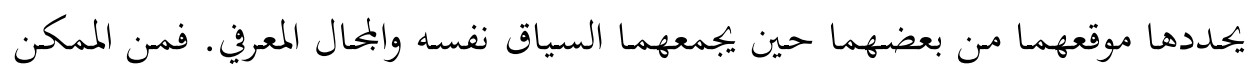
اجتماع مفهوم كلي ومصطلح جزئي في مقام واحد كاجتماع مفهوم المقاصد ومصطلح القياس، وبالاستناد إلى ملحظ الكلية والجزئية وحده يكون الرجحان وان والقوة هنا للمفهوم على حساب المصطلح.

إذن، فالعلاقة بين المفاهيم أعقد من التبسيط الذي يعدها متكافئة ومتعادلة لبحرد

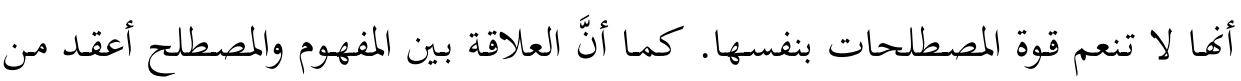

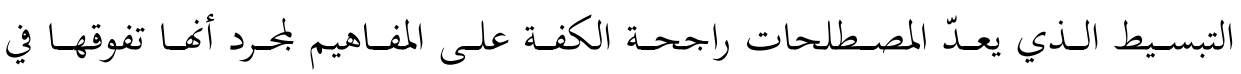
خصيصتي الاتفاق والنضج. غير أننـا في هـذا المستوى مـن الدراسـة سـنتناول علاقـة المنهج والمـذهب مـن الزاويـة التبسيطية، لأن المعالجة الدقيقة تنتمي لصورة جزئية أخرى من صور الإشكال المفهومي؛ وهي الصورة المتعلقة بالشبكة المفهومية. فهي الموضع الأنسب لبحثث تفاوت المفاهيم في

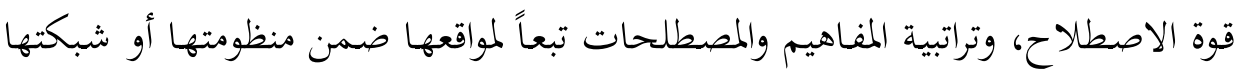
المفهومية وضمن بحالها المعريف. قـد يبـدو أنَّ الحكـم بتكافؤ المفـاهيم وبرجحـان المصطلحات في ميزان الاصطلاح

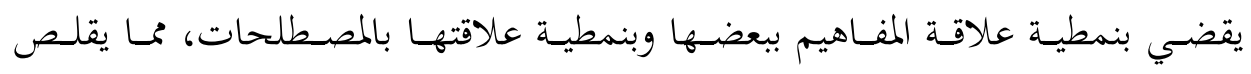

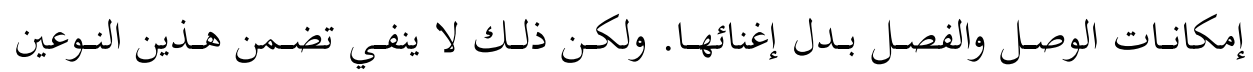

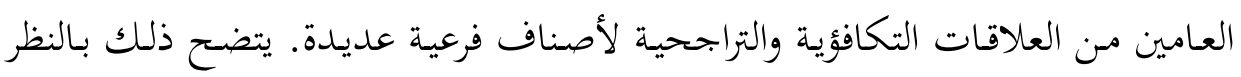

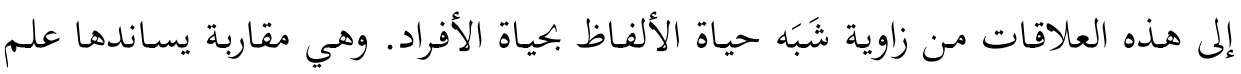

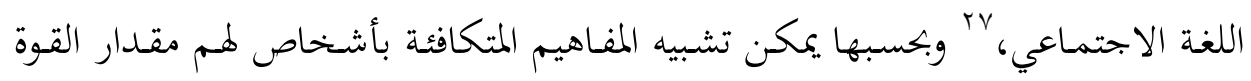

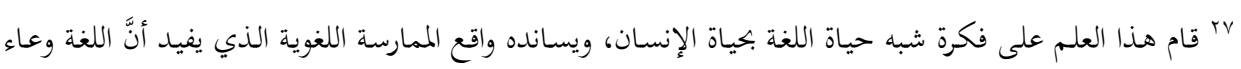

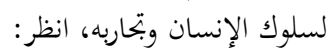

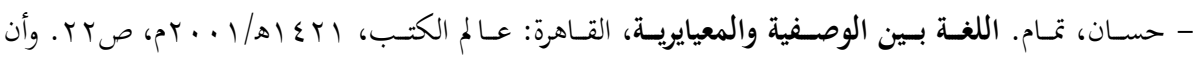

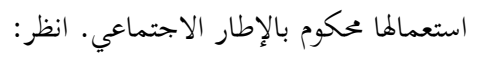

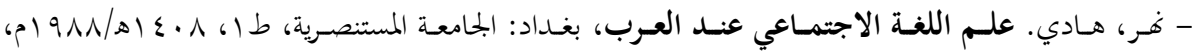




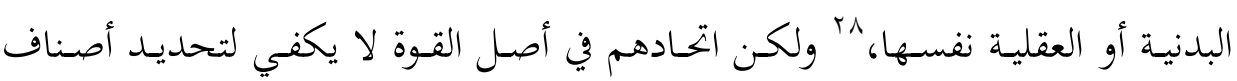

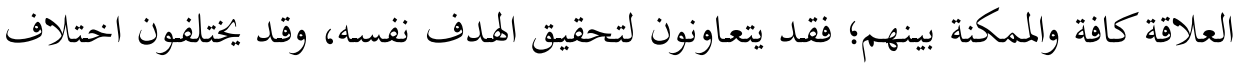
تنوع أو تضاد. ويمكن تشبيه رجحان المصطلحات على المفاهيم بأشخاص يتفاوتون في

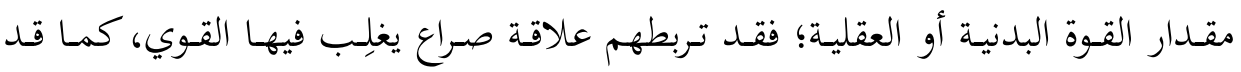
يكصل بينهم توافق فيعين القوي الضعيف.

المعتى العلاقي - إذن- لا ينحصـر في علاقتي التكـافؤ والـتراجح، ولكنـه يتضـمن

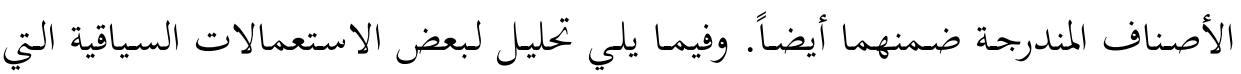

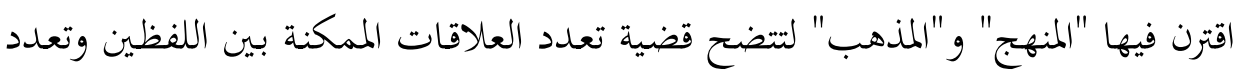
المعاني العلاقية المتولدة عنها، وأثر ذلك في إغناء إمكانات الوصل والفصل.

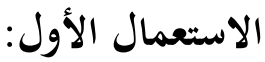

وهو مستفاد من قول محمد أبو زهرة في المذهب: "المذهب يقتضي أن يتكون من منهاج علمي لفريق من الدارسين الباحثين يبنون فيه أصولاً لتفكيرهم متميزة واضحة، ثم يكون لكل منهاج طائفـة أو مدرسة تعتنق هذه الأصول، وتدافع عنها وتقويها بموالاة

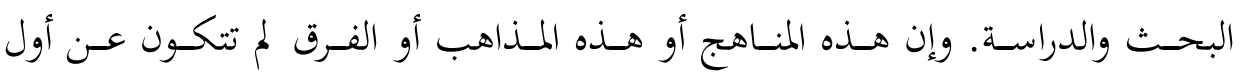

وهذا التشبيه حاضر في المباحث التنظيرية والتطبيقية لهذا العلم، ويظهر في:

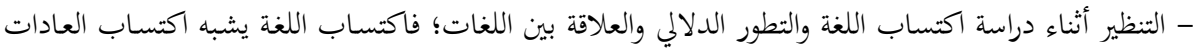

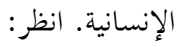
- حسان، اللغة بين الوصفية والمعيايرية، مرجع سابق، صه V. والتطور الدلالي جريان تاريخي وطبيعي للغة

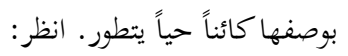

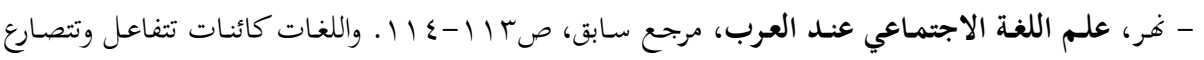

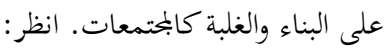

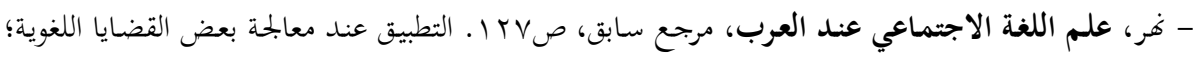

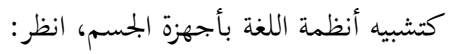

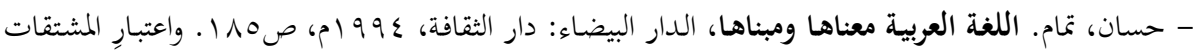

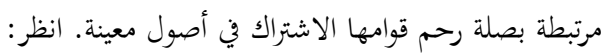

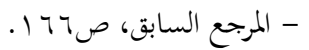

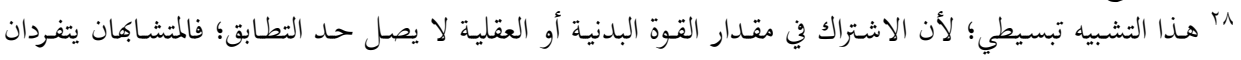
بخصائص ميزة تعود على التساوي التام بالإبطال. 
خلاف، بل إنَّ الخلاف يبتدئ، ثم بعد ذلك تتبلور الأفكار المختلفة، ويؤصل كل رأي،

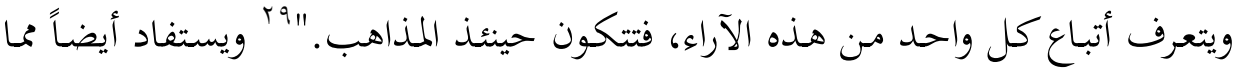

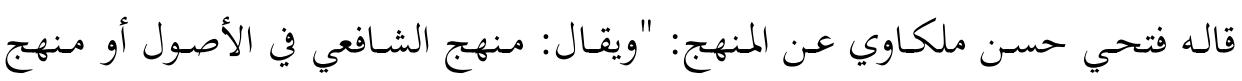

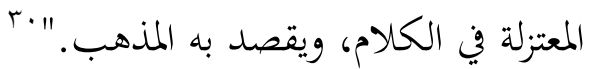

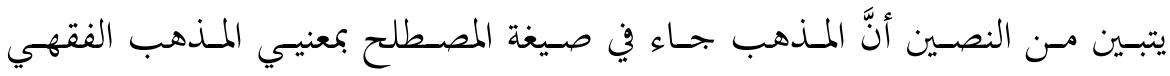
والكالامي، وأن المنهج جاء في صيغة المفهوم. إذن، فالعلاقة بين المنهج والمذهب علئ علاقة

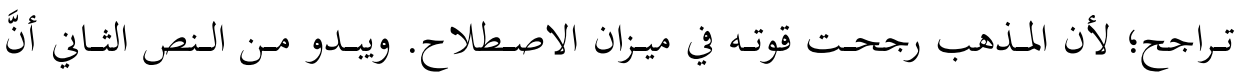

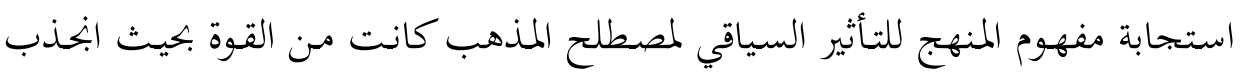
المفهوم للتعبير عن مضمون المصطلح نفسه.

يقضي التراجح بـانجراف المفهوم نحو المصطلح إلى حـد مطابقة معنى المنهج لمعنى المذهب، مما يوحي بضعف قيمة المنهج وتواري خصوصيته الدلالية، وقد يؤثر ذلك سلباً

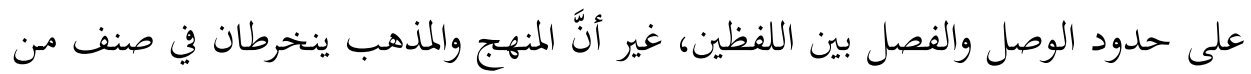

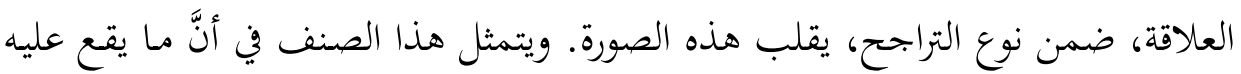

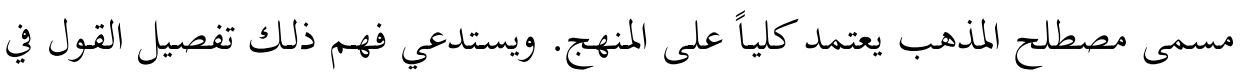

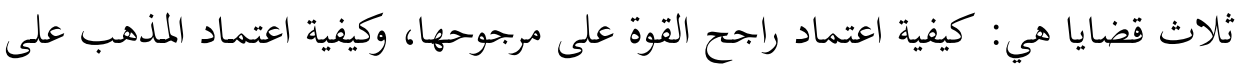

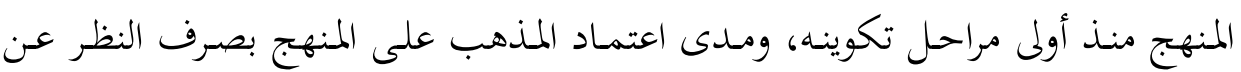

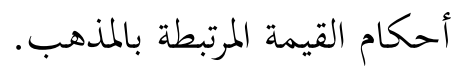

تتضح القضية الأولى بمقارنة حياة الألفاظ بحياة الأفراد؛ فعلو درجة المصطلح على

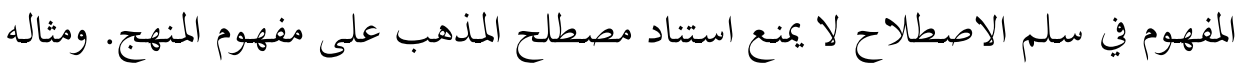

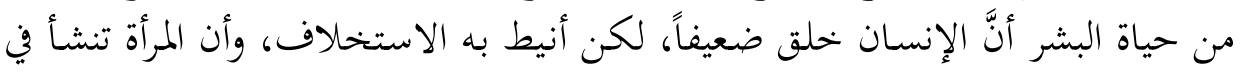

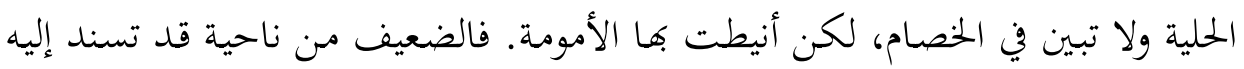

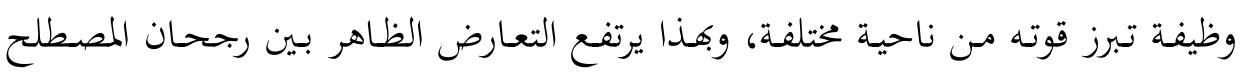

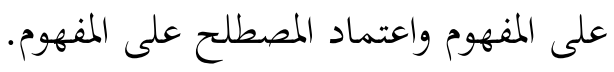
9+ أبو زهرة، محمد. تاريخ المذاهب الإسلامية في السياسة والعقائد وتاريخ المذاهب الفقهية، القاهرة: دار الفكر

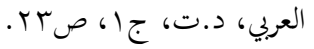

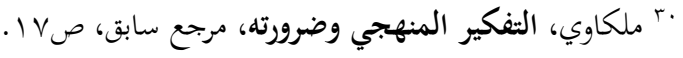




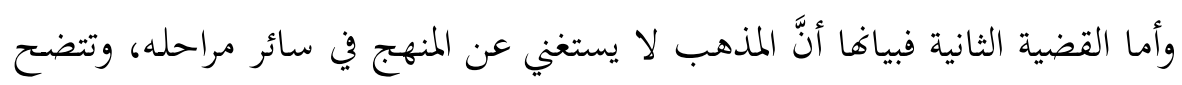

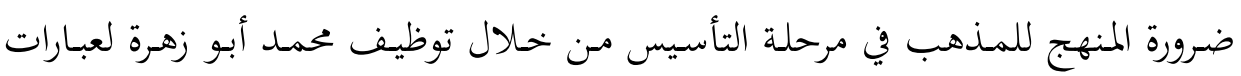

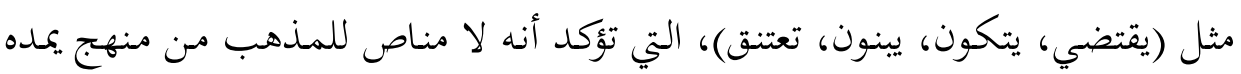

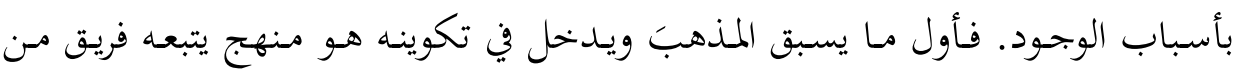

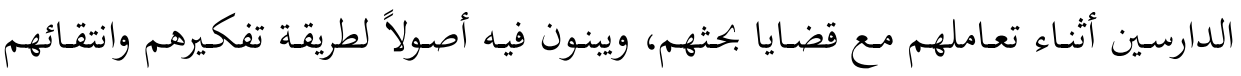

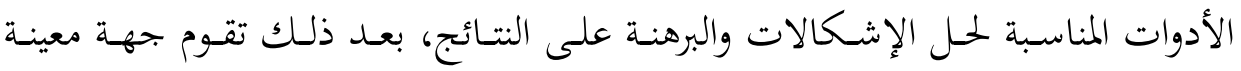

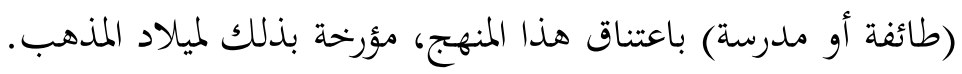

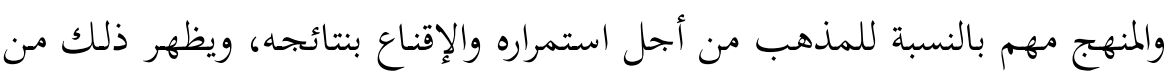

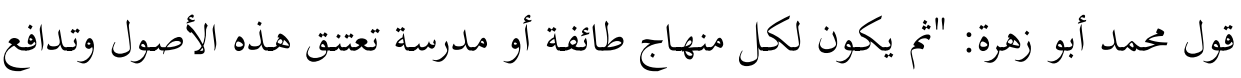

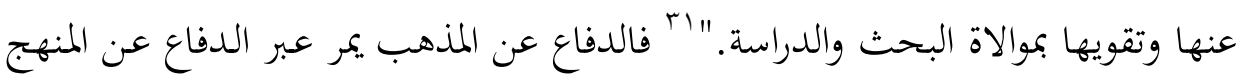

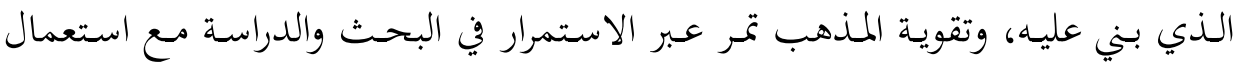

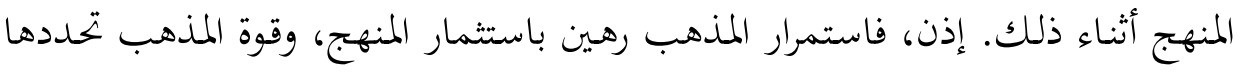

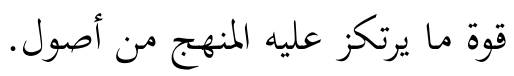

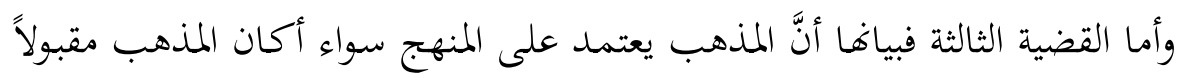

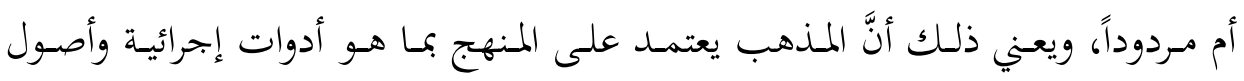

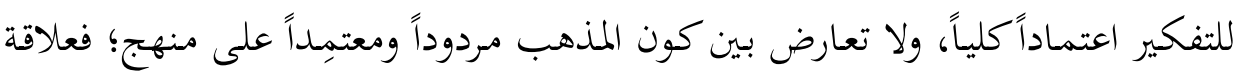
المنهج بالمذهب ليست حبيسة صورة نمطية يفضي فيها الاعتماد على المنهج إلى صحة

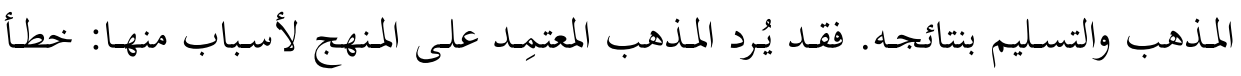

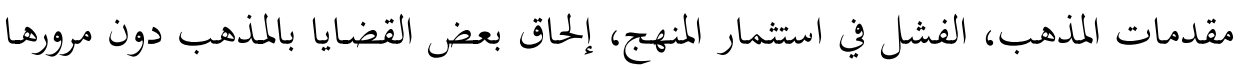
عبر مصفاة المنهج، اعتماد المذهب على منهج غير سليم.

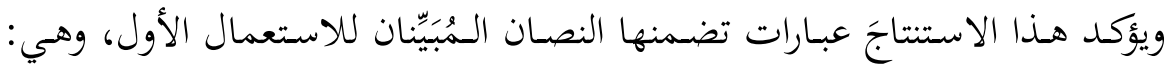

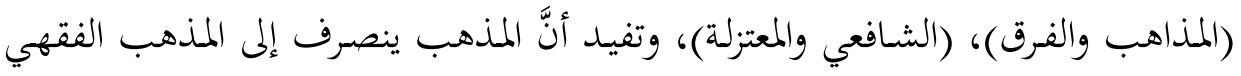

"ا أبو زهرة. تاريخ المذاهب الإسلامية في السياسة والعقائد وتاريخ المذاهب الفقهية، مرجع سابق، ج)،

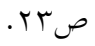




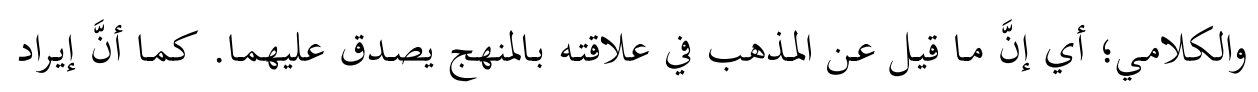

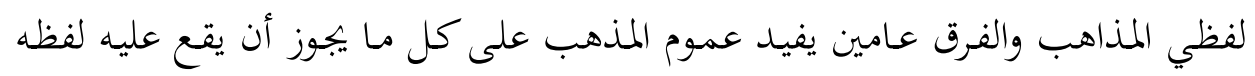

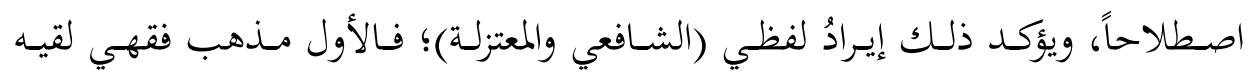
المسلمون بالقبول، والثاني مذهب كلامي أثثار مواقف متباينة.

واستثمار استجابة المنهج والمذهب لعلاقتهما السياقية ببعض أكّد النتائج التي أوصل

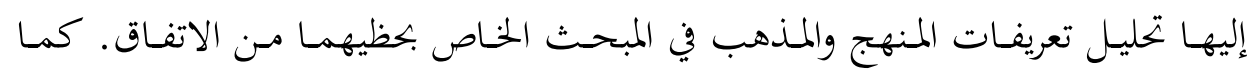
أضاف ذلك الاستثمار فوائد أخرى للفصل والوصل، لمنهات منها:

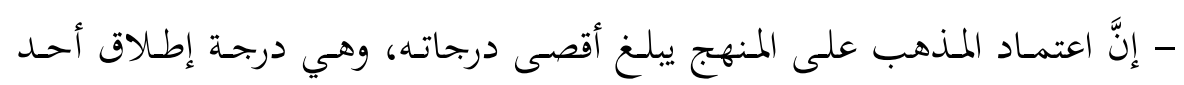

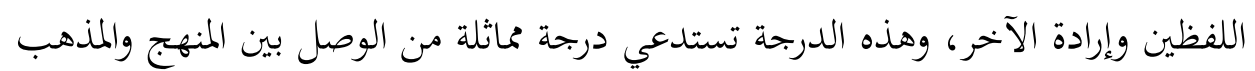

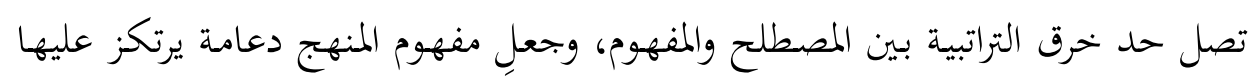

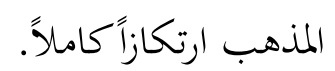

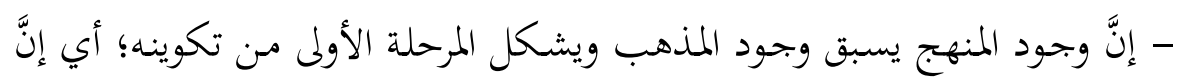

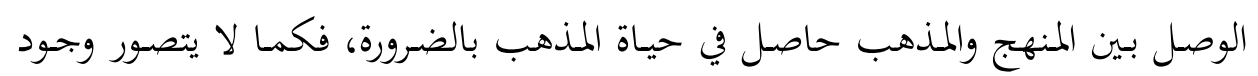

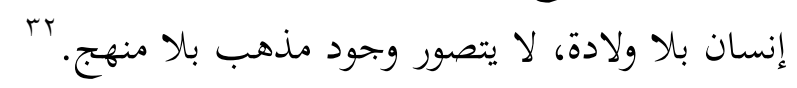

وسبب اختيار المنهج ليَكون مـن حياة المذهبب بمثابة مرحلة الولادة، بـدل اختيار

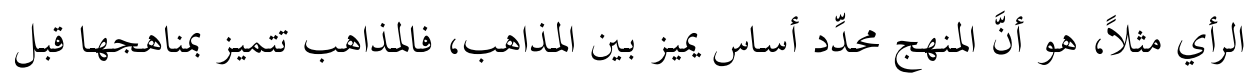

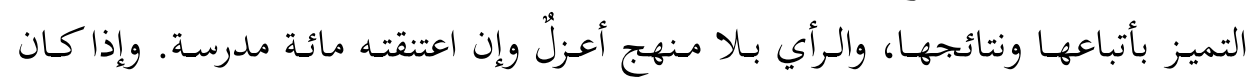

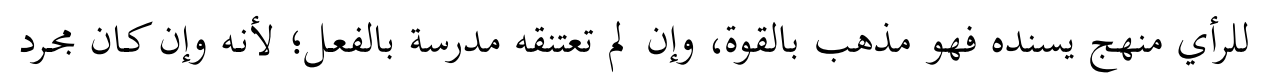

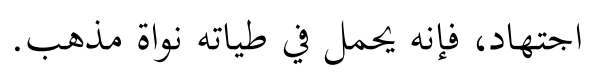

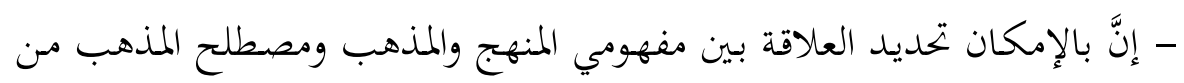

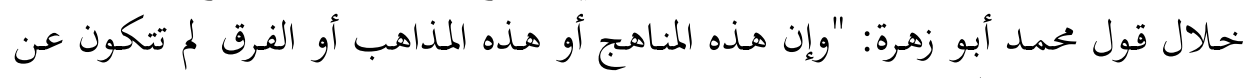

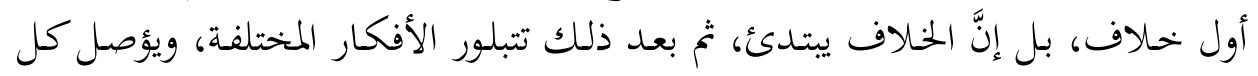

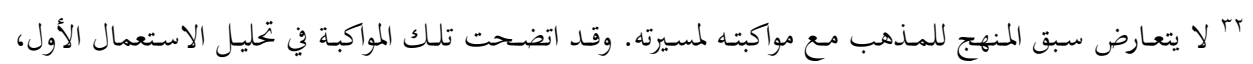

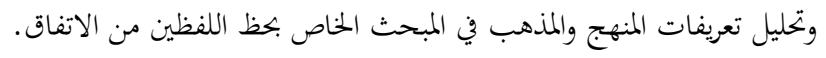


رأي." "آبموجب هذا الكلام تمر حياة المذهب بمرحلة تسبق ولادته، وتشبه المرحلة الجنينية

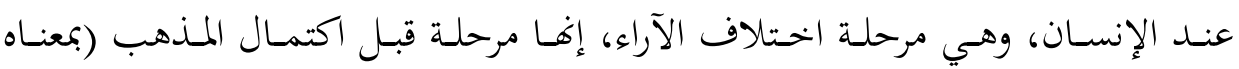

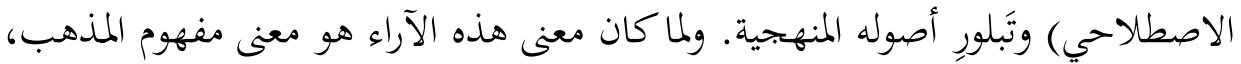

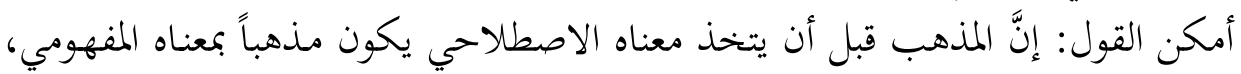

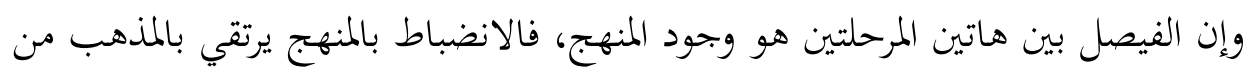
مستوى المفهوم إلى المصطلح.

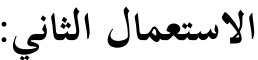

وهو مستفاد مـن قول نور الـدين زمـام: "يتضـمن المـدخل المنهجي (...) جـانبين

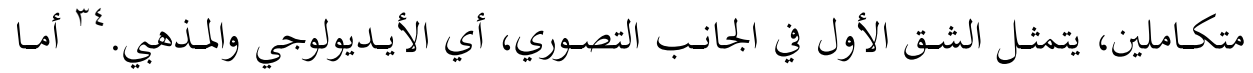

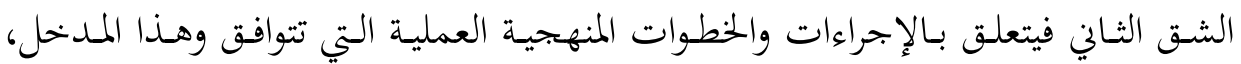

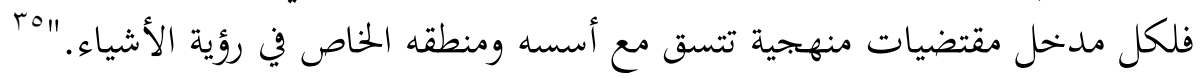

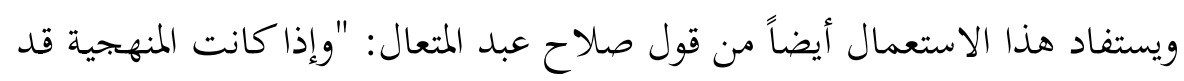

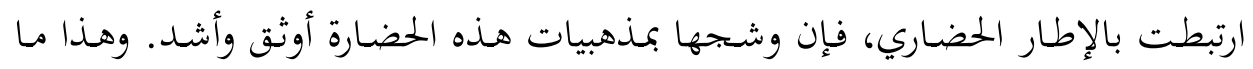

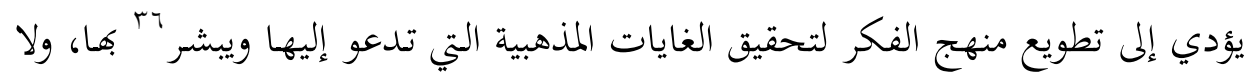
يقتصر ذلك فقط على الحمدود النظرية للمـنهج، بـل يمتـد إلى المنهجية التطبيقية لنتـائج

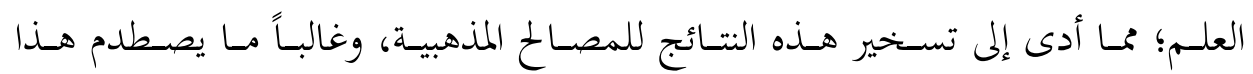

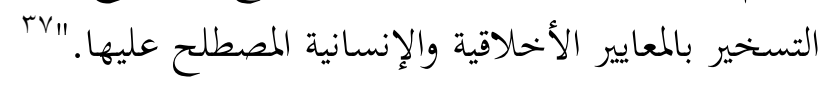

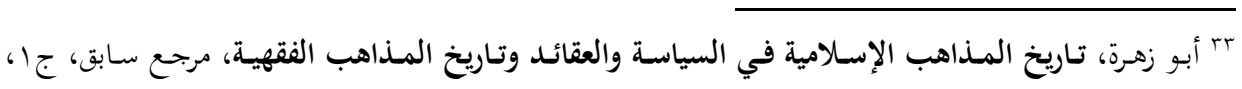
ص صזr.

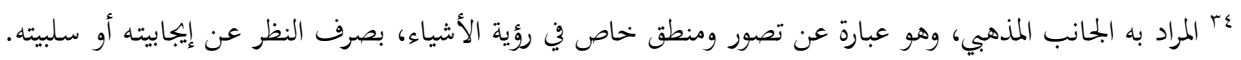

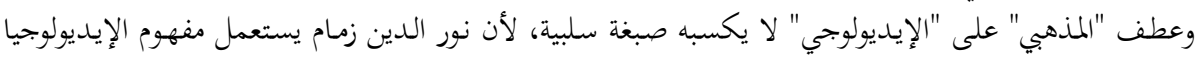

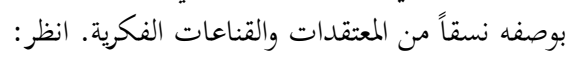
- زمام، نور الدين. إشكالية المدخل المنهات الفكية الإسلامي في حقل السوسيولوجيا، في الرابط التالي: http://knol.google.com/k

$$
\begin{aligned}
& \text { "ror بلمرجع السابق. }
\end{aligned}
$$

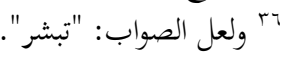

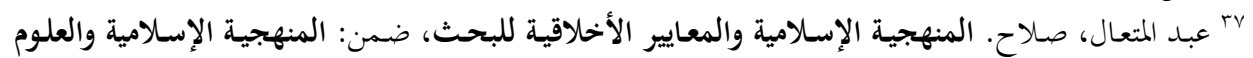

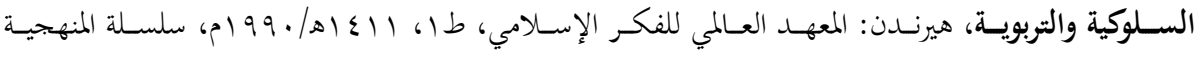

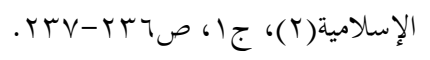


يبرز النصان العلاقة المتكافئة بين مفهومي المنهج والمذذهب، فالمنهج مفهوم معنـاه بحموعة إجراءات وخطوات عملية، والمذهب مفهوم معناه تصور ومنطق خحاص في رؤية الأشياء. ويوضح نور الدين زمام هذا التكافؤ حين يبين أنَّ استجابة المفهومين لتأثيرهما السياقي على بعضهما كانت من التساوي بحيث يمثلان شقين متكاملين لمدخل واحسد.

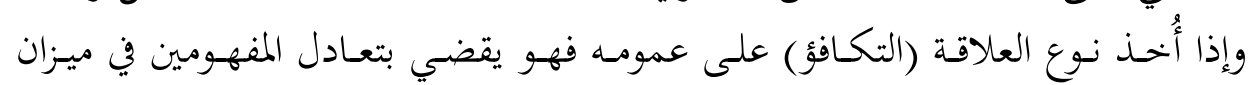
الاصطلاح، وفي التأثيرِ والتأثر، مما يوحي بنِديتهما والاعتمادِ المتبادل والمتساوي بينهما.

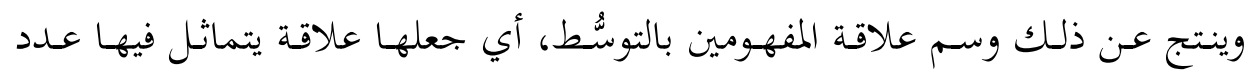
مواضع الوصل والفصل.

وعلى الرغم من ذلك، فبإن المنهج والمذهب ينخرطان في صنف من العلاقة (ضمن

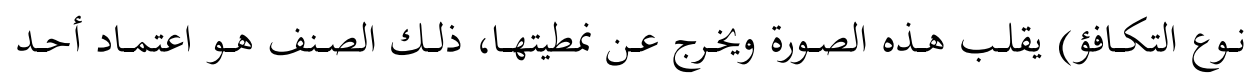
المتكافئين (المنهج) على الآخر (المذهب) وتأثره به.

ينسجم هذا الصنف من العلاقة مع ما خلص إليه تحليل الاستعمال الأول من أنَّ

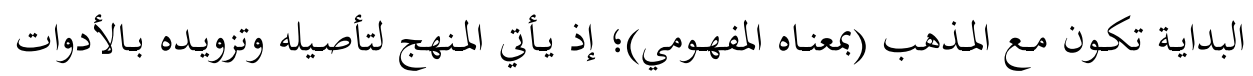

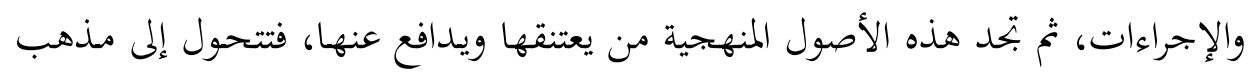

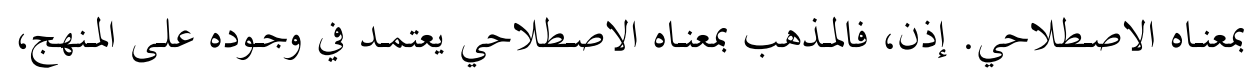
والمذهب بمعناه المفهومي يؤثر في تشكيل أصول المنهج. وتتضـح بتحليل الاستعمال الثاني للمـنهج والمـذهب أربع قضايا هي: كيفية تبعية

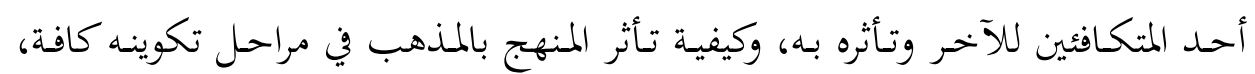

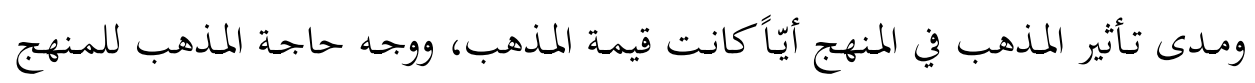
على الرغم من تأثر المنهج بالمذهب وتبعيته: - القضية الأولى يوضحها قول نور الدين زمام: "فلكل مدخل مقتضيات منهجية

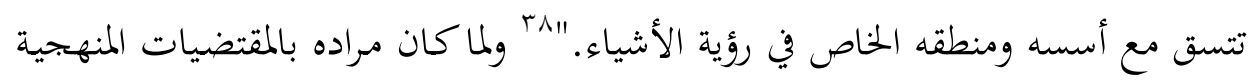

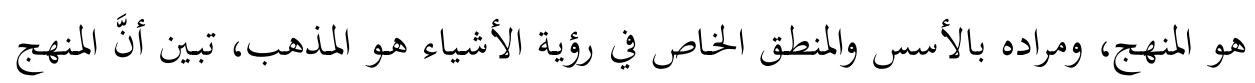

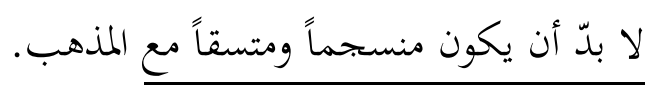
^^^زمام، إنكالية المدخل المنهجي الإسلامي في حقل السوسيولوجيا، مرجع سابق. 
ونفهم كيفية تبعية أحد المتكافئين للآخر بمماثلة حياة الألفاظ لحياة الأفراد؛ فأبناء

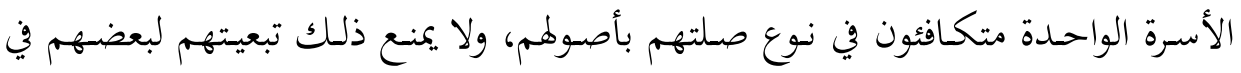

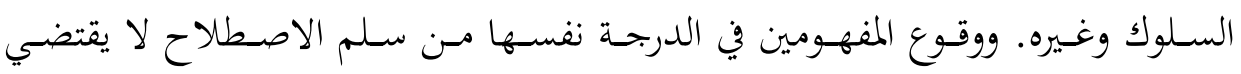

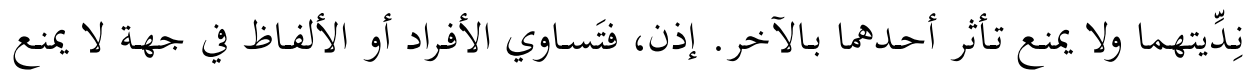

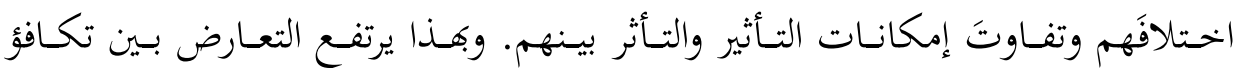
مفهومي المنهج والمذهب في درجة الاصطلاح، وتبعية المنهج للمذهب وتأثره به. - القضية الثانيـة تتعلق بكيفية تأثر المنهج بالمـذهب منذذ بداية تكوينه، وبياهـا أنَّ

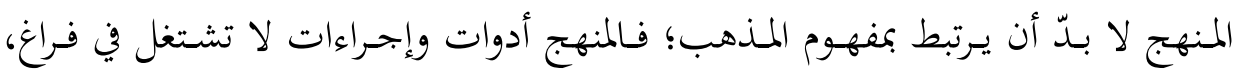
ولذلك تلزمه قضايا يعالجها ويُعمَل فيها، والمعالجة والإعمال تتولاهما جهة لها لمأيها رأيها بإزاء

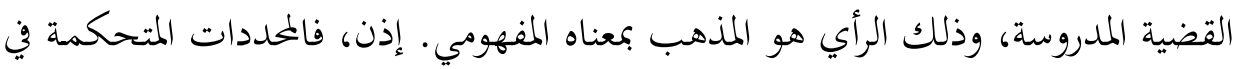
المنهج تفرضها طبيعة الموضوع المدروس ورؤية دارسه، وتُبرز نصوص الاستعمال الثاني تأثر المنهج بمذهبية الباحثين عبر عبارات مثل (تتوافق)، (تتسق)، (تطويع)، (تسخير). إنَّ جعـل العنصـر المـؤثر في المـنهج هـو الأسـس والمنطق الحــاص في الرؤيسة يفيـد أنَّ

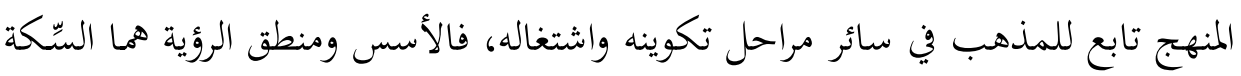
التي تحكـم مسـار المـنهج. ويصـرح النصـان الخاصـان بالاسـتعمال الثـاني بتبعيـة المـنهج

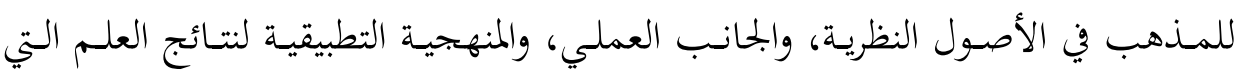
تُطََّع للمصالح المذهبية.

- القضية الثالثة تتعلق بتأثير المذهب في المنهج أيّاً كانت قيمة المذهب. وبياها أنَّ مذهبية الدارس ورؤيته للموضوع تتحكم في اختيار مفردات المنهج، ويتأكد ذلك التأثر

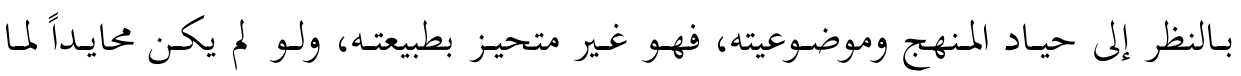
أمكن لجميع المذاهب أن تعتمد على المناهج وتطوعها لخدمتهاديا. يؤكد النصان الخاصان بالاستعمال الثاني تأثر المنهج بالمذهب في سائر أشكاله؛ إذ

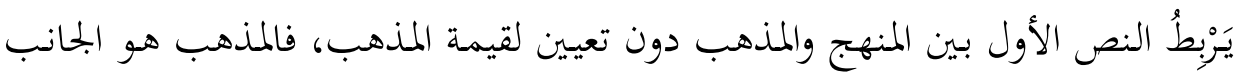

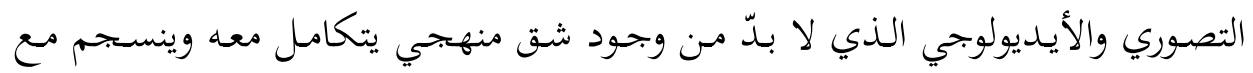




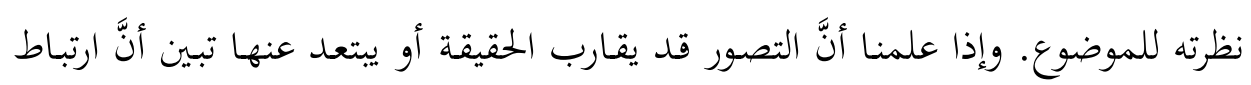

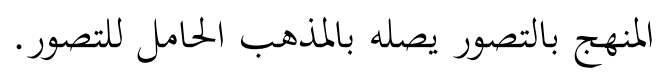

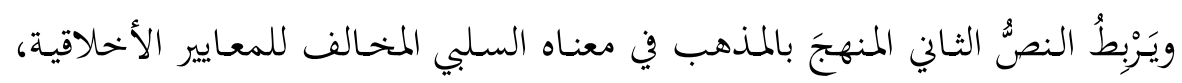

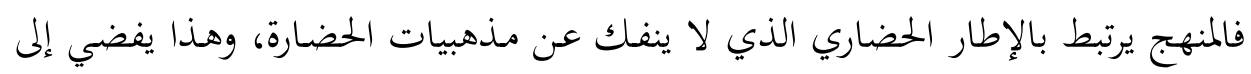

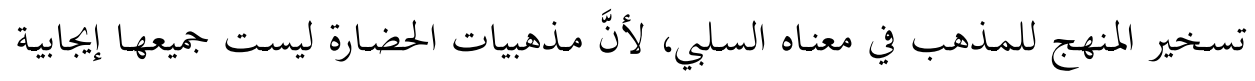
وصائبة.

إنَّ ربط المنهج بالمعنى السلبي للمذهب يبين أنَّ علاقة المنهج بالمذهب ليست دائماً

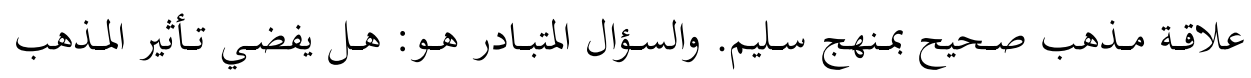
السبي في المنهج إلى جعل المنهج غير سليم أو لا يفضي إليه؟

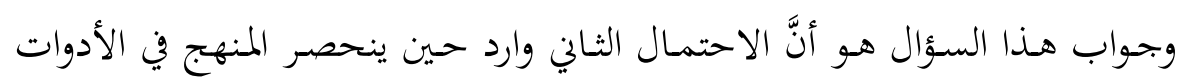

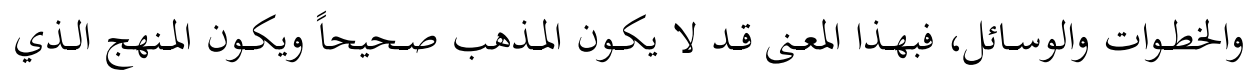

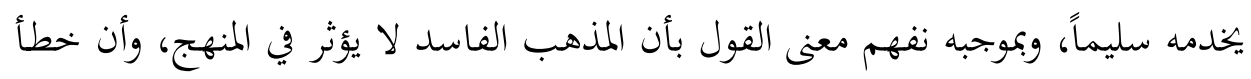

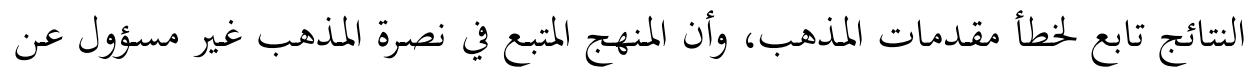

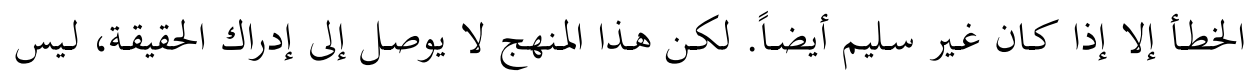

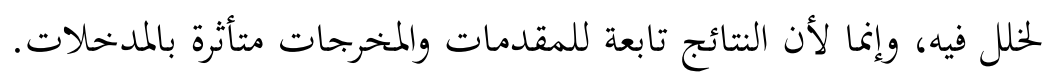
ويفضي الأخذ بالاحتمال الثاني إلى الفصل بين حال المنهج وحال المذهب؛ فمدى

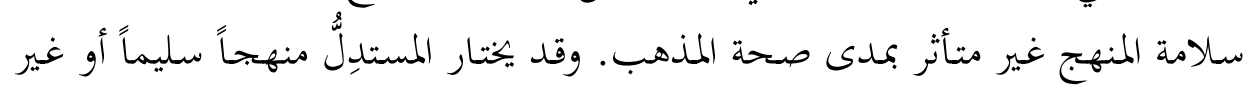

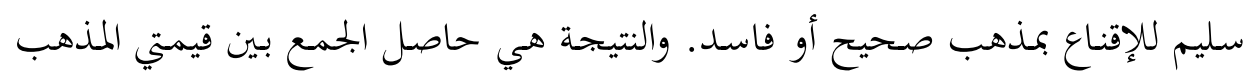
والمنهج.

الاحتمال الأول هو الراجح، لأنَّ نصوص الاستعمالين الأول والثاني جعلت المنهج

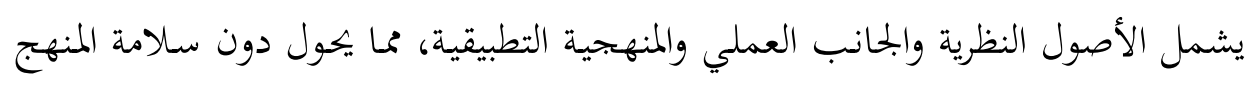

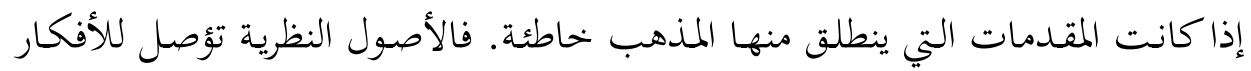

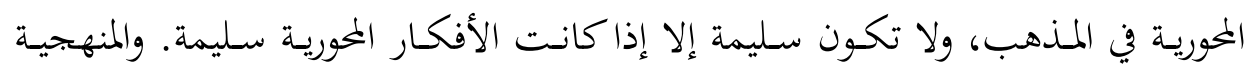

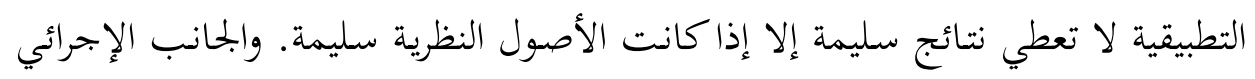


يتشـكل (في حـال خطـأ مقـدمات المـذهب) مسن خطوات إجرائيـة غـير معتبرة، أو مـن خطوات إجرائية معتبرة مسخرة لخدمة أهداف مغرضة.

إنَّ الاحتمال الأول ينحو بمسألة الوصل والفصل منحى مخالفاً للاحتمال الثاني، فهو

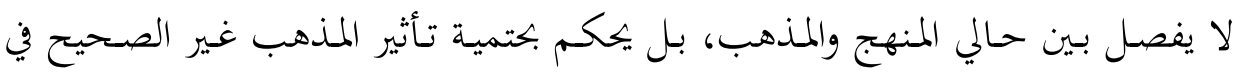

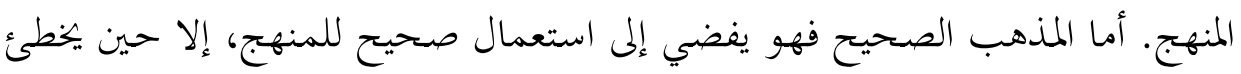

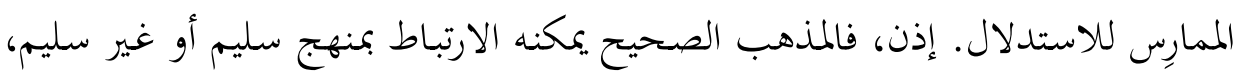
والمذهب الفاسد لا يرتبط إلا بمنهج غير سليم. والنتيجة هي حاصل جمع قيمتي المذهب

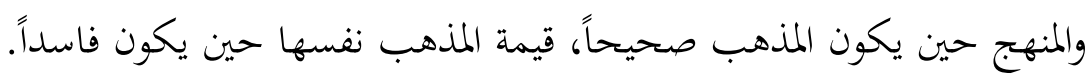
- القضسية الرابعـة تبـين أنَّ المـذهب بمعنـاه المفهـومي يحتـاج للمـنهج مثلمـا احتاجـهـ المـذهب بمعنـاه الاصطلاحي، يعني ذلك أنَّ العنصر المتأثر (وهـو المنهج) يصبح محدِّداً لمصير المذهب. فلا بدّ من وجود منهج للفكر يستند إليه المذهب، ليحقق الغايات التي ئي

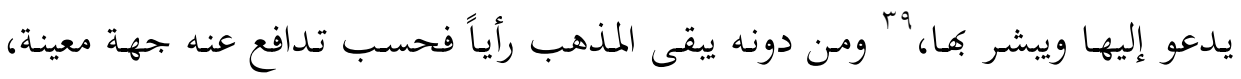

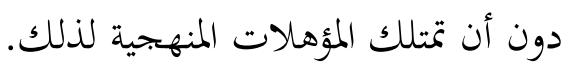

\section{خاتمة:}

إن تقديم حل فائي لأي إشكال يتطلب دراسته باستفاضة، ومـن كل الزوايا حتى تلتحم جزئيات صورته كافة. ولما كانت الصورة التي اشتغلت عليها هذه الدراسة جزءاً من

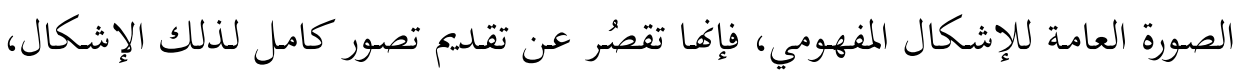
ولا تصدر أحكاما فائية عنه.

والصورة الجزئية التي ركزت عليها هذه الدراسة هي الكشف عن تفاوت حظ المنهج

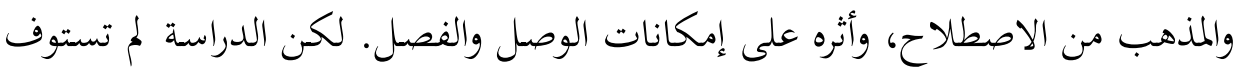
أبعاد تلك الصورة كافة، وإنما حلَّكَت بعضى تعريفات اللفظين واستعمالاتمما لاستخلاصِ

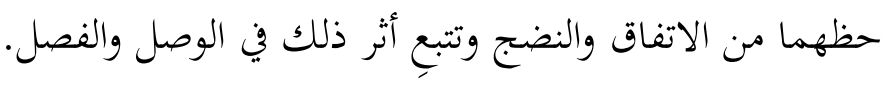


لم تقدم هذه الدراسة حلا هائيا للإشكال المفهومي في صورته الجزئية التي اشتغلت

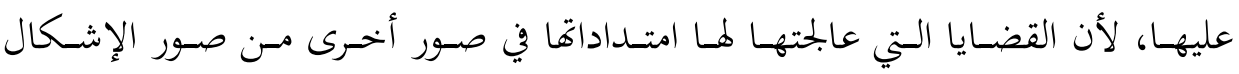

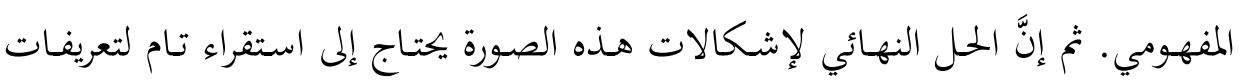
واستعمالات المنهج والمذهب، واستقراء كهذا ينبغي أن تنهض به المؤسسات والأعمال الفهال

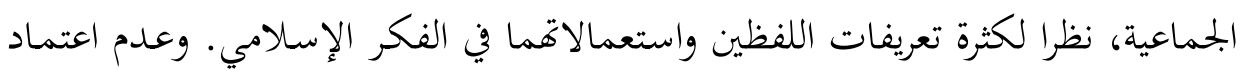

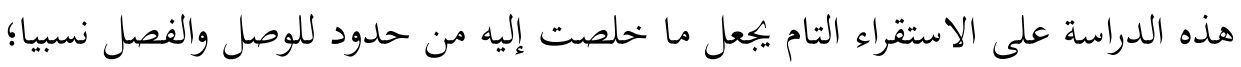

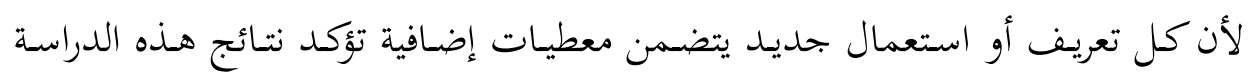
وتطورها أو تفندها وتغيرها.

ومن النتائج الإيجابية لهذه الدراسة أهـا لفتت الانتباه إلى بعض مفاتيح البحت في

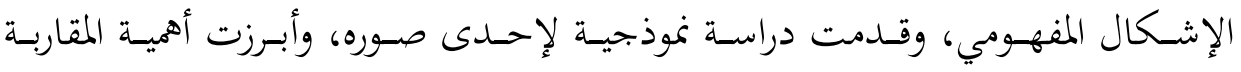
الشمولية لكل بعد من أبعاد كل صورة في ضوء بقية أبعاد الصورة نفسها وفي ضوء أبعاد

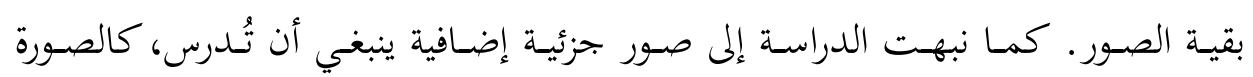

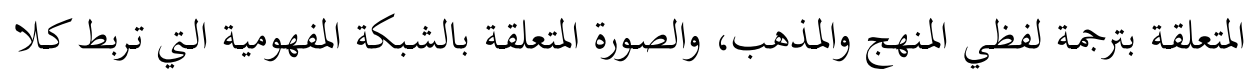

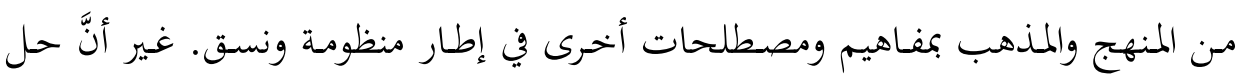

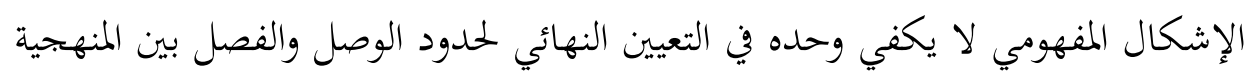

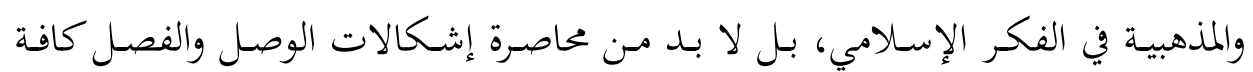
انطلاقا مما أسفر عنه حل الإشكال المفهومي من نتائج. ومن بين الإشكالات الإضافية التي ينبغي دراستها، تلك التي تتعلق بالجوانب النظرية والعملية المعيقة لتعيين حدود الوصل والفصل. ومنها ما يأتي: - إنَّ أحكام القيمة التي تعتري المنهج والمذهب تكون أحيانا نسبية، مما يفضي إلى لهاب الاختلاف في تقديرها باختلاف زوايا النظر.

- إنَّ بعض مفردات المنهج وخطواته الإجرائية قد لا تحتفظ بمعياريتها المطلقة، بل

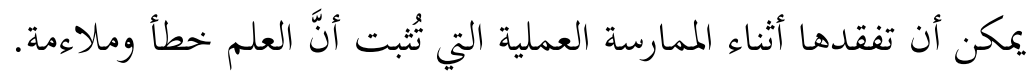


- إنَّ المنهجيـة تقتضي أن يسبق الاستدلالُ الاعتقـادَ في جو مستقل عن المصـالح

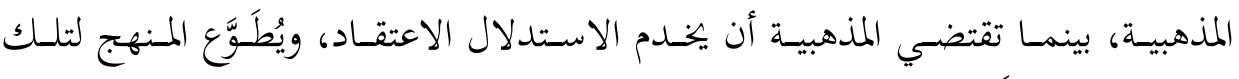

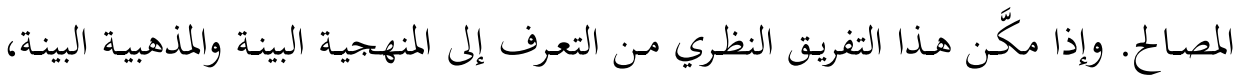

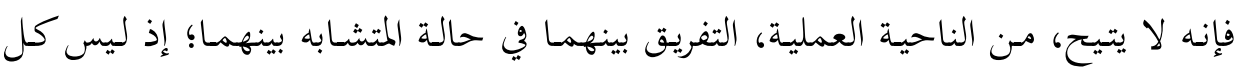

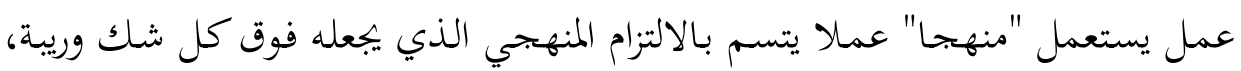

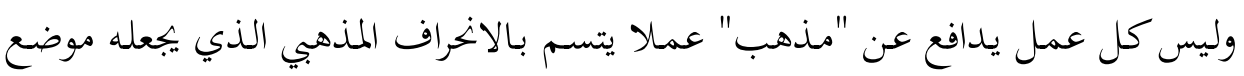
شك وريبة.

- إنَّ الظـاهرة الإنسـانية معقـدة يخـتلط فيهـا الـذاتي بالموضـوعي، ويسـتفحل هـــا

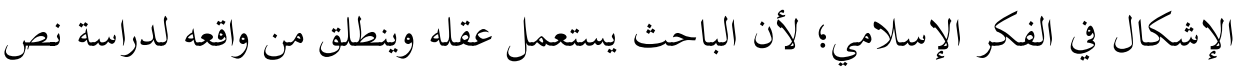
يخصه. وقد لا توجد مسافة كافية بين الذات والموضوع، أي بين الباحثث والنص، وبين

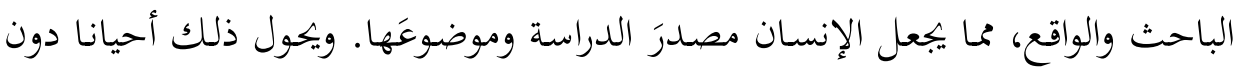
التمييز في عمل الباحث بين التحيز المقبول والمذهبية المغرضة. - إنَّ كل ممارسـة علميـة أو عمليـة تخضـع للقبليـات المعرفيـة، سواء أكانـت أغراض

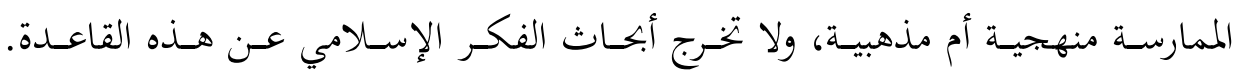
والإشكال الذي تثيره القبليات هو صعوبة تقييمها ومعرفة مدى تأثيرها؛ لأن تشكيلها محكوم بثلاثة متغيرات هي: إطلاقيةُ النص الشرعي، ونسبيةُ التعقل البشري، وبتحددُ الواقع على نحو يؤثر في فهمنا للنص، ونظرتنا لحدود صلاحيات العقل في ذلك الفهم. 